\title{
Destinasyon Kalite Algısını Etkileyen Faktörler: Güneydoğu Anadolu Bölgesinde Bir Araştırma
}

\author{
Factors Effecting the Perception of Destination Quality: A Research in the \\ Southeast Anatolian Region
}

\section{Sedat ÇELÍK* Beykan ÇiZEL $^{* *}$}

Öz: Turizmin sosyo-kültürel, çevresel, ekonomik ve sosyal psikolojik etkilerinden dolayı destinasyonlar gelen turistlere en iyi ürün ve hizmeti sunmak için çaba sarf etmektedirler. Güneydoğu Anadolu Bölgesi destinasyonu da sahip olduğu tarihsel birikimi ve kültürel çeşitliliği ile turizm sektörünü geliştirmeye çalışmaktadır. Turizm destinasyonlarının algılanan hizmet kalitesi önemli bir konudur. Turistlerin destinasyonu kalitesinden memnun olmaları tekrar gelmelerini ve başkalarına olumlu tavsiyelerde bulunmalarını sağlayabilmektedir. Bu makalede turistlerin destinasyon kalite algısında seyahat motivasyonu, kişilik özellikleri ve demografik özelliklerin yordama gücü incelenmiştir. Güneydoğu illerinden Şanlıurfa ve Gaziantep'i ziyaret eden yerli turistlere uygulanan anket ile toplanan verilere lojistik regresyon analizi uygulanmıştır. Turistlerin algıladıkları destinasyon kalitesinde eğitim düzeyinin, kişiliğin ve destinasyonda geceleme sayısının etkili olduğu, ancak seyahat motivasyonu, yaş, medeni durum, destinasyona geliş sayısı gibi değişkenlerin etkili olmadığı tespit edilmiştir. Araştırma bulguları yazın desteği ile tartışılmış ve yorumlanmıştır. Araştırma sonuçlarının uygulamacı ve araştırmacılara ışık tutacağı öngörülmektedir.

Anahtar sözcükler: Destinasyon Kalitesi, Seyahat Motivasyonu, Kişilik, Gaziantep, Şanlıurfa

\begin{abstract}
Due to the socio-cultural, environmental, economic and social psychological influences of tourism, tourism destinations are making efforts to provide the best products and services to tourists. The Southeastern Anatolia Region as a tourism destination also tries to develop the tourism industry, through its historical resources and its cultural diversity. The perceived quality of service provided by tourism destinations is an important issue. Tourists can return to a destination of good quality and provide positive referrals fort his destination to others. In this article, the effect of travel motivation, personality traits and the demographic characteristics of tourists in terms of destination quality was investigated. Logistic regression analysis was applied to collected data by questionnaire applied to local tourists visiting Şanlıurfa and Gaziantep from the South-Eastern provinces. It has been determined that the level of education, personality and the number of nights spent in the destination are influential in the quality perceptions of the destination made by the tourists, but variables such as travel motivation, age, marital status, and the number of arrivals at a destination are not effective. The research findings were discussed and interpreted support from the literature. It is thought that the results of this research will cast light for the practitioner and the researcher.
\end{abstract}

Keywords: Destination Quality, Travel Motivation, Personality, Gaziantep, Şanlıurfa

\footnotetext{
* Yrd. Doç. Dr., Şırnak Üniversitesi, Turizm ve Otel İşletmeciliği Yüksekokulu, Şırnak. s.celik@sirnak.edu.tr

** Prof. Dr., Akdeniz Üniversitesi, Turizm Fakültesi, Antalya. beykan@akdeniz.edu.tr

Bu çalışma Beykan ÇİZEL danışmanlığında, Sedat ÇELIKK tarafından Akdeniz Üniversitesi Sosyal Bilimler Enstitüsü’nde 2017 yılında tamamlanan Doktora Tezinden üretilmiştir.
} 


\section{Yazın Taraması}

\section{Destinasyon Kalitesi}

Turizm endüstrisinde süreklilik ve rekabette avantaj sağlayabilmek için kalitenin müşteri tarafindan algılanması oldukça önemli (Woods ve Deegan 2003). Üretici kaliteli bir ürün veya hizmet sunduğunu düşünebilir. Ancak müşteri bunu eksik veya hatalı algıladığı takdirde onun için kaliteli olmaktan çıkar. Bu durumda gerçek ve algılanan kalite ortaya çıkar. Gerçek kalite üreticinin hedeflediği ürün veya hizmeti sunmasıdır. Ancak algılanan kalite, müşterinin sunulan ürünü algılayış düzeyidir. Bu noktadan bakıldığında üreticinin sunduğu hizmet veya ürün ile müşterinin algıladığı hizmet ve ürün arasındaki farkı kapatmak işletmelerin ve destinasyonların en önemli görevlerindendir. Bundan dolayı işletmeler ve destinasyonlar, memnuniyet ve kalite araştırmaları ile müşterinin sesini dinleyerek göremedikleri hataları düzeltme ve müşteri gözünden kaliteyi yakalayabilme olanağı bulurlar. Böylelikle müşterinin ne istediği ve müşteriyi çeken unsurların ne olduğu anlaşılabilir (Ribeiro Soriano 2002). Bu sayede işletme ve destinasyon yöneticileri, tanıtım ve pazarlama stratejilerini daha doğru bir şekilde belirleyerek rekabet avantajı sağlayabilirler. Destinasyonun her bir unsuruna yönelik turistlerin kalite algılarının nasıl olduğunu ortaya koymak ve bu algılarının tekrar gelmelerini etkileyip etkilemediğini tespit etmek, destinasyon yöneticilerinin değerlendirmelerinde ve durumun daha net bir şekilde anlaş1masında yarar sağlar (Žabkar vd. 2010).

Destinasyon kalitesi, turistin tatil süresince yararlandığı turistik ürün ve hizmetlerin mükemmelliğine yönelik yapılan değerlendirme olarak ifade edilebilir (Wang, Zhang, Gu ve Zhen 2009). Araştırmacılar destinasyona yönelik çalışmalarında destinasyon bileşenlerini farklı boyutlar altında ele almışlardır. Buhalis $(2000,98)$ destinasyonu; attractions-çekicilikler, accessibility-ulaşılabilirlik, amenities-konfor, available packages-hazırlanmış paketler, activities-aktiviteler, acillary services-yardımcı hizmetler gibi altı özelliği üzerinden değerlendirmiştir. Buna karşın, Cooper, Fletcher, Gilbert ve Wanhill (1993) destinasyonu dört boyut; López-Toro vd. (2010) 11 boyut ve Della Corte, Sciarelli, Cascella ve Del Gaudio (2015) 14 boyut, Kozak ve Nield (1998) 11 boyut ile araştırmışlardır. Araştırmalarda görüldüğü gibi destinasyonlar farklı boyutlarda incelenebilir, ancak destinasyon ölçümlerinin destinasyona özgü olarak araştırılması daha doğru bir seçim olacaktır. Deniz turizmi, kültür turizmi veya kırsal turizminin yapıldığ destinasyon özellikleri birbirlerinden farklı olduğundan, farklı boyutlarla ölçülmesi doğru olur. Ayrıca destinasyon kalite boyutlarından ziyade bunların yorumlanması ve değerlendirilmesi üzerinde durulmalıdır (Žabkar vd. 2010). Örneğin deniz olmayan bir destinasyonda sahilin temizliği ile ilgili bir soru oldukça yanlış olur.

Destinasyonun sahip olduğu nitelikler araştırmacılar tarafindan; algılanan destinasyon hizmet kalitesi (Shonk 2006; Chen vd. 2011; Tosun vd. 2015), destinasyon çevre kalitesi (Awaritefe 2003), destinasyon imaj1 (Ghada Abdalla 2008; Tasci 2009; Baloglu, Henthorne ve Sahin 2014; Kim ve Park 2015), destinasyon rekabetçiliği (Buhalis 2000; Kozak 2001), turist memnuniyeti (Aksu, İçigen ve Ehtiyar 2010; Yuksel, Yuksel ve Bilim 2010; Della Corte vd. 2015), destinasyon kalitesi (Žabkar vd. 2010; López-Toro vd. 2010; Ünlüönen ve Çimen, 2011; Eusébio ve Vieira 2011; Özyurt ve Kantarci 2014) gibi farklı perspektiflerde ele alınmıştır.

\section{Kişilik}

Kişilik kavramı 1930'lu yıllardan sonra kişilik psikolojisi alanının bir disiplin olarak ortaya çıkmasıyla bilimsel olarak gelişmeye başlamıştır (McAdams 1997). Kişilik kavramı, insanların etkileşim sırasında tepki ve kendisini gösterme biçimini kapsamaktadır (Biçer 2011, 400). Araştırmacılar kişiliği, çalışmalar alanlarına göre farklı bakış açıları ile el almışlardır. Örneğin 
psikologlara göre kişilik; bireyin kendine has ve ayırıcı davranışlarını içermekteyken, davranış bilimleri açısından kişilik; bireysel farklılıkların bireyin davranışlarda ve yaşam biçiminde vücut bulmasidir (Aykut 2013).

Araştırmacılar kişiliğin dışa vurumu olan davranışları bireyin bilinçaltında yatan düşüncelere, kalıtımsal özelliklerine, bireylerin nasıl öğrendikleri ve öğrendiklerini nasıl uyguladıkları konuları üzerinde durmaktadır (Şentürk 2014, 29). Ayrıca çalışmalarda kişisel farklılıkların temelinde genetik, sosyo-kültürel, coğrafi, aile yapısı, (Robbins ve Judge 2013) ve kişinin içinde bulunduğu durum (Kondalkar 2007) gibi unsurlar dikkate alınmaktadır. Kişiliğin oluşmasında birçok unsurun etkili olması ve araştırmacıların aynı kişilik özelliklerine farklı isimler vermelerinden dolayı çalışmalar arasında ortak bir tanım ve kişilik özelliklerini belirlemek zorlaşmaktadir (Borges ve Gibson 2005, 5).

Kişilikle ilgili birçok kuram geliştirilmiştir. Ayırıcı özellikler kuramı, kişilerin kendilerine özgü davranışlarının neler olduğunu ortaya koymaya çalışan kuramlardır. Bu kuramların iki önemli varsayımı vardır. Birincisi araştırmacılar kişilik özelliklerinin zamanla değişmediğini ikincisi ise bu özelliklerin duruma göre de değişmediğidir. Bu Ayırıcı özellikler ile ilgili yapılan ilk çalışmalardan biri Allport (Gordon Allport ve Floyd Allport) kardeşlerin "Kişilik özellikleri: Sinıflandırılması ve Ölçümü” adlı çalışmalarıdır (Dal 2009, 80). Bu kuramcılarından biride Raymond Cattell'dir. Cattell önceden oluşturulan kişilik özelliklerinin gruplayarak ve faktörler oluşturarak belirlenebileceğini belirtmiştir. Uzun süren çalışmaları sonucunda Allport ve Odbert'in 4500 olan kişilik özelliklerini 171'e indirgeyebilmiştir. Faktör analizi sonucunda da 16 faktörlü bir kişilik envanteri ortaya çıkmıştır. Bu envanter dünyada çok sık kullanılan ve güvenilir olan Beş Kişilik Faktör ölçeğinin temelini oluşturmaktadır (Kondalkar 2007, 62).

Beş Faktör Kişilik Kuramı kişiliğin özelliklerini ortaya koyarak incelenmesinde kullanılan en önemli kuramlardan biridir (Miller ve Lynam 2001; Ekehammar ve Akrami 2007). Paul Costa ve Robert McCrae tarafından geliştirilen Beş Faktör Kişilik Kuramı bütün kişilik özelliklerini bünyesinde toplayan ve bu özellikleri geniş kapsamlı olarak açıklayan bir kuramdır (Merdan 2013, 142). Bu ölçeğin günümüzdeki kullanım şekliyle ilk kullanan 1963'te Warren Norman'dır (Morgan, 2011). Beş faktör kişilik ölçeğinin boyutları; Dışadönüklük (Extraversion), Uyumluluk (Agreeableness), Sorumluluk (Conscientiousness), Duygusal denge-nevrotik (Emotional Stability), ve Deneyime Açıklık (Openess to Experience) şeklindedir (Costa ve McCrae 1995).

Kişiliğin turist davranışlarını açıklamada beş faktör kişilik kuramının önemli payı vardır. Kişiliğe göre turistlerin ne satın alabilecekleri, motivasyonları ve tekrar gelip gelmeyecekleri gibi davranışları önceden belirlenebilir. Kişilik pazarlama, ürün konumlandırma, master planlama, yeni tatil beldelerinin geliştirilmesi, turizm paketlerinin oluşturulması gibi alanlarda kullanılabilir. Ayrıca satın alma davranışı, medya seçimi, yenilikçilik, bölümlendirme, korku, sosyal etki, ürün seçimi, risk alma, tutum değişimi ve daha birçok şey kişilik ile ilişkilendirilmektedir (Kassarjian 1971, 409). Bu yüzden kişilik turizm alanında, en iyi bilinen ve potansiyel olarak en yararlı psikolojik kavramlardan birisidir. Buna karşın çoğunlukla göz ardı edilmektedir (Jackson ve Inbakaran 2006).

Um ve Crompton (1990), seyahat edilecek destinasyonun seçilmesinde etkili olan unsurlara yönelik bir model ortaya koymuştur. Modelde, dış girdiler, iç girdiler ve bilişsel yapılar yer almaktadır. Dış girdileri; bilgilendirme amaçlı sunulan medya, promosyon malzemeleri, başkalarının söyledikleri (sosyal uyaranlar) ve destinasyonu fiili olarak ziyaret etme unsurları yer almaktadır. İç girdiler ise turistlerin sosyal psikolojik unsurları (değerler, motivasyon, kişilik ve tutum) ve sosyo-demografik unsurlarından oluşur. Kişilik ve destinasyon seçimi ilişkilerinin 
araştırıldığı birçok çalışma mevcuttur. Bunların en bilineni Plog (2001)'un allosentrik ve psikosentrik turist kişilikleridir. Psikosentrik kişilerin temel motivasyonları eğlenme ve dinlenmedir. Dolayısı ile yerel halkla pek etkileşim içinde olmazlar. Allosentrik kişiler ise kalabalık, bilinen destinasyonlardan ziyade yeni keşfedilmiş ve pek kimselerin bilmediği yerlere gitmek isterler ve yerli halkla etkileşimde bulunup onları tanımayı, kültürlerini öğrenmeyi isterler (Andreu, Kozak, Avci ve Cifter 2005). Plog (2001) hangi turist tiplerinin hangi destinasyonlara gittiklerini ortaya koymuştur. Alosentrik kişilerin kimsenin fazla gitmediği, bilinmeyen Afrika, Asya, Güney Avrupa gibi az gelişmiş destinasyonları tercih ettikleri görülmektedir. Psikosentrik kişilerin ise pek çok kişinin gittiği ve bilinen destinasyonlara gittikleri görülmüştür.

Literatür taraması sonucunda, turistlerin kişilikleri ile memnuniyetleri ve kalite algıları ile ilişkili olduğunu ortaya koyan çok sayıda araştırmanın olduğu görülmektedir: Mooradian ve Olver (1997), Sönmez ve Graefe (1998), Carr (2001), Tan, Der Foo ve Kwek (2004), Gountas ve Shaw (2001), Matzler, Faullant, Renzl ve Leiter (2005), Gountas ve Gountas (2007), Morad Rezaei, Rezaei, Alipour ve Salehi (2011), Lin ve Worthley (2012), Faullant, Matzler ve Mooradian (2011), Siddiqui (2012), Oliveira, Cherubini ve Oliver, (2013), Jani ve Han (2014), Haghi ve Ooshaksaraie (2015).

\section{Seyahat Motivasyonu}

Motivasyon; "bir kişinin davranışını uyandıran, yönlendiren ve bütünleştiren içsel bir faktördür" (Murray, 1964 akt. Iso-Ahola 1982, 257). Literatürde motivasyon ile ilgili birçok teorinin olduğunu görmekteyiz. Bu teoriler temelde kapsam ve süreç teorileri olarak adlandırılmaktadır (Koçel 2012). Kapsam teorileri motivasyonun ihtiyaç ve isteklerin karşılanması için belirli bir davranışa yönelmesinden dolayı ortaya çıktığını vurgularlar. Süreç teorileri ise kapsam teorilerinin düşüncesine ek olarak çevresel faktörlerinde motivasyonu ortaya çıkardığını ortaya koymuştur (Kerse 2016, 4).

İnsanların istek ve ihtiyaçları ortaya çıktığında ve karşılanmadığında bir dengesizlik ortaya çıkar. Bu dengesizliği yok etmek için bir davranışta bulunur. Bu nedenle stresten kurtulma, dinlenme, yeni yerle görme, rutin ortamdan kurtulma gibi istek ve ihtiyaçlarını karşılamak için seyahate çıkma gereksinimi duyarlar. Bu bağlamda insanların seyahat etme, tatile gitme istekleri bir motivasyon unsurudur (Yazıcıŏlu ve Akbulut 2016, 3232).

Seyahat motivasyonu genellikle seyahat amacı ile eş anlamlı kullanılmaktadır ve turist tiplerini, rollerini ve deneyimlerini vurgular (Pearce ve Caltabiano 1983). Seyahat motivasyonu; bireyleri belirli bir seyahat/tatil deneyimi yaşamaya yönelten nedenler olarak tanımlanabilir (Harman 2014, 110). Başka bir deyişle, kişinin belirli bir turistik amaca yönelik bir şekilde "hareket etmeye yönelten ihtiyaç ve tutumlar dizisidir" (Pearce 1991 akt. Bright 2008).

Lee $(2009,218)$ "Turist davranışını açıklarken turist motivasyonları öncelikli ele alınması gerektiğini” belirterek seyahat motivasyonunun önemini vurgular. Turizm yönetimi açısından turist motivasyonlarının araştırılması oldukça önemlidir. Çünkü turist motivasyonlarını tespit ederek çeşitli motivasyon tipleri elde edilir. Bu sayede turizmin hangi çeşidini geliştirmemiz ile ilgili önemli bilgi verir. Fiziksel motivasyonlar için rekreasyon, spor, sağlık, kültürel motivasyonlar için kültür turizmi, manevi motivasyonlar için dini turizm, hac vb. gibi. Turist motivasyonu araştırmalarında turist motivasyonlarının temelleri için çeşitli sınıflandırmalar yapılmıştır: Öncelikle biyolojik sebepler öne sürülmüştür, turist motivasyonun ikinci nedeni ise psikolojik unsurlar olarak ortaya konulmuştur. Bu tüketicinin bir toplumda yaşadığı gerçeğinden ortaya çıkmaktadır. Bu durumda amaç tatmin etmektir. Diğer sınıflandırma ise ana/temel ve seçici nedenlerdir. Ana neden seyahat ihtiyacının olduğu düşüncesine cevap vermekte iken seçici 
neden belirli bir destinasyon, seyahat biçimi veya seyahat acentasını seçme sürecini ifade etmektedir (Mahika 2011, 15).

Seyahat motivasyonları turistlerin farklı ülkelere, kültürlere, kişiliklere sahip olmaları ve farklı turizm ürünlerini tercih etmelerinden dolayı oldukça heterojen bir yapıya sahiptir (Kozak 2002; Harman 2012). Bu heterojen yapıdan dolayı turist motivasyonlarını ortaya koyan evrensel bir teori olmasa da birçok kuram (Dann, 1977; Crompton, 1979; Iso-Ahola, 1982; Pearce, 1982; Mill, 1985) ortaya konmuş ve araştırmalar yapılmıştır (Heitmann 2011). Seyahat motivasyonunu ele alan kuramlardan biri soysal-psikoloji açısından Dann'ın 1977'de ele aldığ dışlanmışlık (anemie) ve kendini gerçekleştirme (ego-enhancement) kuramıdır (Dann 1981). Dann 1977 yılında ziyaretçilerin Barbados'a yönelik tutumlarını belirlemek için yaptığı anket çalışmasında itici (push) faktör olarak dışlanmışlık (anemie) ve kendini gerçekleştirme (ego-enhancement) faktörlerini ele almıştır (Fodness 1994, 556). Dann'a göre insanlar anomik bir toplumda yaşadığ için sosyal etkileşimi azalmaktadır. Bu durumda sosyal yaşamdan dışlanmışlık hissedilmektedirler. Dolayısı ile ev ve rutin ortamdan kaçmak bir seyahat motivasyonu ortaya çıkmaktadır (Rızaoğlu 2012, 62). İnsanlar aynı zamanda benlik veya egolarını yükseltmek ve kendilerini gerçekleştirmek için seyahat etmektedirler. Dışlanma ve kendini gerçekleştirme faktörleri sosyal psikolojik unsurlar olup iten ve çeken faktörler teorisinin temelini oluşturmaktadır (Çetin 2015, 13). Crompton (1979) turist motivasyonları olarak sosyo-psikolojik ve kültürel motivasyonlara vurgu yapmıştır. Sosyo-psikolojik motivasyon unsurları; olağan çevreden kaçma, kendini değerlendirme ve keşfetme, rahatlama, prestij, geri çekilme, akrabalık ilişkileri ve sosyal etkileşimin kolaylaşması, kültürel motivasyon unsurları; yenilik ve eğitim şeklinde ifade etmiştir. Crompton (1979) burada hem iten hem çeken unsurlara dikkat çekmiştir. Seyahat motivasyonlarını ortaya koyan teorilerden en fazla kabul gören teori "itme ve çekme" teorisidir (Uysal, Li, Sirakaya-Turk 2008). Turist motivasyonunun itme ve çekme faktörleri temelinde şekillenmesinde Crompton'un, Dann'ın ve Iso-Ahola'nın çalışmalarının etkisi büyüktür (Jönsson ve Devonish 2008, 399; Heitmann 2011).

Seyahat motivasyonunun destinasyon seçimi (Jang ve Cai, 2002), davranışsal eğilimler (Konu ve Laukkanen, 2009), turist memnuniyeti (Lee, 2009; Çetin, 2015), hizmet kalitesi (Chen vd. 2011), destinasyona yönelik tutumlar (Wong, Cheung ve Wan, 2013; Hsu, Cai ve Li, 2010) üzerinde etkili olduğu araştırmalarda görülmektedir. Böylelikle seyahat motivasyonunun önemini görebilmekteyiz.

\section{Yöntem}

Araştırmanın örneklemi, araştırmanın modeli ve hipotezleri, veri toplama araçları ve verilerin analizi konuları aşağıda açıklanmıştır.

\section{Evren ve Örneklem}

Araştırma, Şanlıurfa ve Gaziantep illerini Nisan-Haziran 2016 tarihleri arasında ziyaret eden yerli turistlerle gerçekleştirilmiştir. Veri toplama aşamasında "Şanlıurfa Bölgesel Turist Rehberler Odası" başkanlığından, bölgeye gelen tur rehberlerinden ve konaklama işletmelerinden yardım alınmıştır. Araştırmada veri setindeki hatalı veriler ayıklandıktan sonra toplam 400 anket elde edilmiştir. Veriler yüz yüze anket tekniği ile toplanmıştır. Ölçek formu turistlere tatillerinin son gününde doldurtulmuştur. Basit tesadüfî örneklem yöntemi kullanılan çalışmada $\% 5$ hata oranı ile ulaşılması gereken kişi sayısı 384 olarak belirlenmiştir (Tabachnick ve Fidell 2006). Dolayısı ile toplanan 400 veri sonuçların genelleştirilmesi için yeterli görülmektedir. 


\section{Veri Toplama Araçları}

Algılanan destinasyon kalitesine ilişkin sorular oluş̧urulurken, literatürden (Duman ve Öztürk 2005; Chen ve Tsai 2007; Zabkar vd. 2010; Eusebio ve Vieria 2011; Tosun vd. 2015) yararlanılmış, uzman görüşleri alınmış ve araştırmanın yürütüldüğü destinasyon alanının nitelikleri göz önünde bulundurularak, algılanan destinasyon kalitesini ölçmek için bir ölçüm aracı geliştirilmiştir. Algılanan destinasyon kalitesi ölçüm aracı toplamda 31 sorudan oluşmuştur. Algılanan destinasyon kalitesi ifadeleri 5'li likert (1-Çok kötü.....5-Çok iyi) kullanılarak sorulmuştur. Ayrıca destinasyonda karşılaşmadıkları hizmetleri belirtmeleri için "O-fikrim yok" seçeneği kullanılmıştır. Kişilik; Costa ve McCare (1985) tarafından ortaya konulan beş faktör (dışa dönük, uyumlu, nevrotik, sorumlu, deneyime açık) kişilik kuramı temelinde Jani'nin (2014)'un kullanmış olduğu soru ifadeleri ( 5 boyut ve 22 ifade) kullanılmıştır. Kişilik ifadeleri 5'li likert (1- Kesinlikle Katılmıyorum..... 5- Kesinlikle Katılıyorum) kullanılarak sorulmuştur. Seyahat motivasyonuna ilişkin ifadeler itme-çekme motivasyon teorisi temelinde ele alınmıştır. İfadeler oluşturulurken Kozak (2002) tarafından seyahat motivasyonlarını ölçmek için kullanılan ölçekten yararlanılmıştır. Belirtilen çalışmalarda 14 ifade 4 boyut olarak ele alınmıştır. Seyahat motivasyonu ile ilgili ifadeler 5'li likert (1- Çok etkisiz.....5-Çok etkili) kullanılarak sorulmuştur. Ayrıca demografik sorular; cinsiyet, medeni durum, eğitim, yaş, aylık ortalama gelir ve geliş sayısı, konaklama yeri, geceleme sayısı, yapılan harcama ve tatil bilgi kaynakları gibi sorular sorulmuştur.

\section{Araştırmanın Modeli ve Hipotezleri}

Yapılan literatür taraması sonucunda destinasyon kalitesinin seyahat motivasyonu (Hsu vd. 2010; Wong vd. 2013), demografik değişkenler (Özyurt ve Kantarci 2014; Jalilvand, Samiei, Dini ve Manzari 2012), kalış sayısı (Özyurt ve Kantarci 2014), geliş sayısı (Tosun vd. 2015) değişkenlerinin algılanan destinasyon kalitesini etkilediği görülmüştür. Ayrıca doğrudan destinasyon kalitesi ile kişilik arasındaki ilişkinin ölçüldüğü çalışmalara rastlanmamıştır. Ancak kişiliğin hizmet kalitesini ve memnuniyeti etkilediği (Tan vd. 2004; Gountas ve Gountas 2007) tespit edilmiştir. Yapılan araştırmalar sonucunda ortaya konulan hipotez ve model aşağıda belirtilmiştir.

H1: Turistlerin destinasyon kalite algıları, ortalamaya göre kalite algısı düşük ve yüksek olarak değerlendirilmesinde (sınıflandırılmasında); kişilerin seyahat motivasyonları anlamlı bir etkiye sahiptir.

H1a: Turistlerin destinasyon kalite algıları, ortalamaya göre kalite algısı düşük ve yüksek olarak değerlendirilmesinde (sınıflandırılmasında); motivasyon boyutlarından "dinlenme" anlamlı bir etkiye sahiptir.

H1b: Turistlerin destinasyon kalite algıları, ortalamaya göre kalite algısı düşük ve yüksek olarak değerlendirilmesinde (sınıflandırılmasında); motivasyon boyutlarından "eğlence" anlamlı bir etkiye sahiptir.

H1c: Turistlerin destinasyon kalite algıları, ortalamaya göre kalite algısı düşük ve yüksek olarak değerlendirilmesinde (sınıflandırılmasında); motivasyon boyutlarından "kültür" anlamlı bir etkiye sahiptir.

H1d: Turistlerin destinasyon kalite algıları, ortalamaya göre kalite algısı düşük ve yüksek olarak değerlendirilmesinde (sınıflandırılmasında); motivasyon boyutlarından "fizik" anlamlı bir etkiye sahiptir.

H2: Turistlerin destinasyon kalite algıları, ortalamaya göre kalite algısı düşük ve yüksek olarak değerlendirilmesinde (sınıflandırılmasında); katılımcıların "kişilik 
özellikleri” anlamlı bir etkiye sahiptir.

H2a: Turistlerin destinasyon kalite algıları, ortalamaya göre kalite algısı düşük ve yüksek olarak değerlendirilmesinde (sınıflandırılmasında); katılımcıların kişilik özellikleri boyutlarından "deneyime açıklık" anlamlı bir etkiye sahiptir.

H2b: Turistlerin destinasyon kalite algıları, ortalamaya göre kalite algısı düşük ve yüksek olarak değerlendirilmesinde (sınıflandırılmasında); katılımcıların kişilik özellikleri boyutlarından "dışa dönük" anlamlı bir etkiye sahiptir.

H2c: Turistlerin destinasyon kalite algıları, ortalamaya göre kalite algısı düşük ve yüksek olarak değerlendirilmesinde (sınıflandırılmasında); katılımcıların kişilik özellikleri boyutlarından "sorumlu" anlamlı bir etkiye sahiptir.

H2d: Turistlerin destinasyon kalite algıları, ortalamaya göre kalite algısı düşük ve yüksek olarak değerlendirilmesinde (sınıflandırılmasında); katılımcıların kişilik özellikleri boyutlarından "uyumlu" anlamlı bir etkiye sahiptir.

H2e: Turistlerin destinasyon kalite algıları, ortalamaya göre kalite algısı düşük ve yüksek olarak değerlendirilmesinde (sınıflandırılmasında); katılımcıların kişilik özellikleri boyutlarından "nevrotik" anlamlı bir etkiye sahiptir.

H3: Turistlerin destinasyon kalite algıları, ortalamaya göre kalite algısı düşük ve yüksek olarak değerlendirilmesinde (sınıflandırılmasında); katılımcıların demografik özellikleri anlamlı bir etkiye sahiptir.

H3a: Turistlerin destinasyon kalite algıları, ortalamaya göre kalite algısı düşük ve yüksek olarak değerlendirilmesinde (sınıflandırılmasında); katılımcıların "cinsiyeti" anlamlı bir etkiye sahiptir.

H3b: Turistlerin destinasyon kalite algıları, ortalamanın üzerinde olması bakımından, kalite Turistlerin destinasyon kalite algıları, ortalamaya göre kalite algısı düşük ve yüksek olarak değerlendirilmesinde (sınıflandırılmasında); katılımc1ların "medeni durumu" anlamlı bir etkiye sahiptir.

H3c: Turistlerin destinasyon kalite algıları, ortalamaya göre kalite algısı düşük ve yüksek olarak değerlendirilmesinde (sınıflandırılmasında); katılımcıların "eğitim durumu" anlamlı bir etkiye sahiptir.

H3d: Turistlerin destinasyon kalite algıları, ortalamaya göre kalite algısı düşük ve yüksek olarak değerlendirilmesinde (sınıflandırılmasında); katılımcıların "yaşı" anlamlı bir etkiye sahiptir.

H4: Turistlerin destinasyon kalite algıları, ortalamaya göre kalite algısı düşük ve yüksek olarak değerlendirilmesinde (sınıflandırılmasında); katılımcıların "destinasyona gelişsayısı" anlamlı bir etkiye sahiptir.

H5 Turistlerin destinasyon kalite algıları, ortalamaya göre kalite algısı düşük ve yüksek olarak değerlendirilmesinde (sınıflandırılmasında); katılımcıların "destinasyonda geceleme sayısı" anlamlı bir etkiye sahiptir.

Yukarıda belirtilen hipotezlere ilişkin ele alınan model Şekil 1'de gösterilmiştir. 


\section{Verilerin Analizi}

Öncelikle verilerdeki kayıp değerlerin yerine ortalamalar yolu ile değer ataması yapılmıştır. Kalite sorularında var olan "0-fikrim yok" seçeneği kayıp veriye dönüştürülmüş (Zabkar vd. 2014). Kayıp verilerin oranı \%10'un üstünde olan ifadeler çok önemli görülmediği takdirde veri setinden çıkarılması uygun bulunmuştur (Çokluk, Şekercioğlu ve Büyüköztürk 2012, 11). Analizlere geçmeden önce veri kalitesini test etmek için normallik ve doğrusallık analizleri yapılmıştır. Çok değişkenli normallik analizi yaparken Mahalonobis uzaklıklarına bakılmıştır. Mahalonobis uzaklığı en yüksek, 2,51 çıkmıştır. \%1'lik anlam düzeyinde t değerleri tablosunda madde sayısına karşılık gelen 3,460'tan büyük veri çıkmamıştır. Dolayısı ile çok değişkenli uç değere rastlanmamıştır. Daha sonra çok değişkenli normal dağılıma bakılmıştır. 65 serbestlik derecesinin karşılığı ,965'tir (Büyüköztürk 2016, 202). Kritik korelasyon katsayısı değeri ise ,971>,965 çıkmıştır. Bundan dolayı verilerin normal dağılım gösterdiğini söyleyebiliriz.

Araştırmaya katılan toplam 400 katılımcıdan elde edilen veriler yardımıyla ölçeğin güvenirlik ve geçerlik çalışmaları gerçekleştirilmiştir. Bu aşamada, iki yarı test tekniği kullanılarak (Büyüköztürk 2016, 182) 400 veri rastgele (tek-çift) iki gruba ayrılmış ve 200 kişilik bu gruplar üzerinden açıklayıcı faktör analizi gerçekleştirilmiştir. Elde edilen ölçeğin faktör yapısı açımlayıcı faktör analizi (AFA) yöntemiyle ele alınmıştır. Doğrulayıcı faktör analizi yardımıyla model veri uyumunun incelenmesi ve değişkenler arasında var olduğu düşünülen ilişkilerin (madde toplam puan korelasonu) test edilmesi amaçlanmıştır (Büyüköztürk 2016, 183). Ayrıca AFA ile belirlenen her bir alt boyut için cronbach alfa katsayıları belirlenerek ölçeğin güvenirliğine ilişkin kanıtlar sunulmuştur. Ek olarak betimsel istatistiklere yer verilmiştir.

Katılımcıların destinasyon kalite algısına ilişkin 27 madde ve 6 boyuttan oluşan kalite ölçeğinde yer alan maddelere göre algı düzeyi düşük ve yüksek olmak üzere iki gruba ayırabilmek amacıyla öncelikle hiyerarşik olmayan kümeleme yöntemlerinden en yakın komşuluk tekniği uygulanmıştır. Ancak analiz sonucunda iki küme oluşmasına rağmen ikinci kümede sadece 8 bireyin yer alması sebebiyle bireyleri düşük ve yüksek algı düzeyi olacak şekilde iki gruba ayırmak amacıyla kesme puanı kullanılmıştır. Kesme puanı belirlenirken katılımcıların Kalite Ölçeğinden elde ettikleri puanların ortalaması hesaplanmış, ortalamanın altında olanlar "düşük" olarak, ortalamanın üzerinde olanlar ise "yüksek" olarak tanımlanmıştır. Buna göre bağımlı değişken için ortalamanın $(=3,72)$ altında olanlar " 0 ” ve ortalamanın üstünde olanlar "1" olarak yeniden kodlanmıştır.

Araştırma kapsamında oluşturulan destinasyon kalite algısının lojistik regresyon yöntemiyle açıklanmasına ilişkin kurulan modelde kalite algısı bağımlı değişken; seyahat motivasyonu, kişilik özellikleri, demografik özellikler ise bağımsız değişkenler olarak kabul edilmiştir. Çalışma kapsamında kullanılan ölçme aracı 3 alt ölçekten meydana gelmektedir. 


\section{Geçerlilik ve Güvenilirlik Analizleri}

Çalışma kapsamında ele alınan alt ölçekler için elde edilen güvenirlik katsayıları Tablo 1'de gösterilmiştir.

Tablo 1. Ölçeklere İlişkin Güvenirlik Analizi Sonuçları

\begin{tabular}{|l|c|c|}
\hline Alt Ölçekler & $\begin{array}{c}\text { Madde } \\
\text { Sayısı }\end{array}$ & $\begin{array}{c}\text { Cronbach } \\
\text { Alpha (a) }\end{array}$ \\
\hline Seyahat Motivasyonu alt ölçeği & 11 & .880 \\
\hline Dinlenme & 4 & .86 \\
\hline Eğlence & 4 & .78 \\
\hline Kültür & 3 & .82 \\
\hline Kişilik Alt ölçeği & 16 & .770 \\
\hline Dışa dönu & 4 & .75 \\
\hline Deneyime açık & 4 & .69 \\
\hline Uyumlu & 3 & .68 \\
\hline Sorumlu & 3 & .64 \\
\hline Nevrotik & 2 & .55 \\
\hline Destinasyon Kalitesi alt ölçeği & 27 & .915 \\
\hline Konaklama & 4 & .92 \\
\hline Fiyat & 4 & .76 \\
\hline Yemek ve misafir & 4 & .74 \\
\hline Yardımcı unsurlar & 3 & .86 \\
\hline Temizlik ve ulaşım & 8 & .85 \\
\hline Otantik & 4 & .84 \\
\hline
\end{tabular}

Tablo 1 incelendiğinde çalışma kapsamında kullanılan alt ölçeklerden elde edilen ölçme sonuçlarının güvenilir olduğu söylenebilir. Kişilik ölçeğine ilişkin alfa değerlerinin yeterli olduğu ancak nevrotiklik boyutunun aldığ değerin düşük olduğu görülmüştür. Bu değer ölçeğin alındığı çalışmada da (Jani, 2014) benzer (0.54) çıkmıştır.

\section{Açımlayıcı ve Doğrulayıcı Faktör Analizi Sonuçları}

Çalışmada birinci aşamada, ölçeğin tek boyutlu olup olmadığını belirlemek amaciyla temel bileşenler analizi yapılmış ve ölçeğin alt boyutları arasında ilişki olmadığı düşünülerek temel bileşenlere göre Varimax dik döndürme tekniği kullanılmıştır (Tabachnick ve Fidell, 2006). Bu aşamada madde yükü .30 'un altında ve farklı boyutlarda yük veren binişik maddeler belirlenmiştir. Ölçekte yer alan maddelerin tamamının faktör yük değerlerinin .30'un üzerinde olduğu görülmektedir (Floyd ve Widaman 1995).

Çalışmada birinci aşamada belirlenen faktör yapısının ikinci aşamada oldukça güvenilir olduğunun belirlenmesinin ardından ölçeğin yapı geçerliğine kanıt sağlamak amacıyla doğrulayıcı faktör analizi uygulamaya karar verilmiştir. Bu kapsamda 400 katılımcıdan elde edilen veri seti kullanılmıştır. Çalışma kapsamında örneklem ile benzerlik gösteren farklı bir gruba ulaşma imkânı olmaması sebebiyle aynı verilere doğrulayıcı faktör analizi uygulanmıştır. Bu aşamada doğrulayıcı faktör analizine geçmeden önce veri setinin sayıltıları karşılayıp karşılamadığı incelenmiştir. Kayıp değerlerin kritik olarak kabul edilen \%5'in altında olması sebebiyle kayıp veri atama yöntemlerine başvurulmamıştır. Verilerin tek değişkenli normallik ve doğrusaldık varsayımlarını karşıladığ1 görülmüştür. Çoklu bağlantı sorunun araştırılmasında ise durum indeksi (CI) değerinin 30'dan, Varyans Artış Faktörü (VIF) değerlerinin 10'dan küçük olması sebebiyle çoklu bağlantı sorunu olmadığı görülmüştür.

\section{Seyahat Motivasyonuna Yönelik AFA ve DFA Sonuçları}

Turistlerin seyahat motivasyonlarına yönelik maddelere uygulanan AFA ve DFA faktör analizi sonuçları aşağıda belirtilmiştir. 
Tablo 2. Motivasyon Ölçeğinin Açımlayıcı Faktör Analizi (AFA) Sonuçları

\begin{tabular}{|c|c|c|c|c|c|}
\hline Boyutlar & İfadeler & $\begin{array}{c}\text { Ortak } \\
\text { Varyans }\end{array}$ & F1 & F2 & F3 \\
\hline \multirow{4}{*}{ 死壹 } & Dinlenme1 & .833 & .857 & & \\
\hline & Dinlenme2 & .619 & .855 & & \\
\hline & Dinlenme3 & .829 & .776 & & \\
\hline & Dinlenme4 & .618 & .669 & & \\
\hline \multirow{4}{*}{ 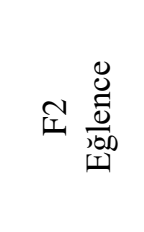 } & Eğlence1 & .724 & & .784 & \\
\hline & Eğlence2 & .683 & & .773 & \\
\hline & Eğlence3 & .704 & & .693 & \\
\hline & Eğlence4 & .449 & & .635 & \\
\hline \multirow{3}{*}{ 的奉 } & Kültür1 & .820 & & & .869 \\
\hline & Kültür2 & .792 & & & .853 \\
\hline & Kültür3 & .602 & & & .659 \\
\hline \multicolumn{3}{|r|}{ Öz değer } & 5,23 & 1,39 & 1,04 \\
\hline \multicolumn{3}{|c|}{ Açıklanan Varyans } & 47,59 & 12,72 & 9,46 \\
\hline
\end{tabular}

Tablo 2 incelendiğinde 4 maddeden oluşan dinlenme alt boyutunun özdeğerinin 5,23 ve açıkladığı varyans miktarının \%47,59 olduğu belirlenmiştir. Toplam 4 maddeden oluşan Eğlence alt boyutunun özdeğerinin 1,39 ve açıkladığı varyans miktarının \%12,72 olduğu belirlenmiştir. Toplam 3 maddeden oluşan kültür alt boyutunun özdeğerinin 1,04 ve açıladığı varyans miktarının \%9,46 olduğu belirlenmiştir.

Tablo 3. Üç boyutlu Motivasyon Ölçme Modeline İlişkin DFA Sonuçları

\begin{tabular}{lccccccc}
\hline Model & $\chi^{2}$ & sd & $\chi^{2} /$ sd & NFI & GFI & CFI & RMSEA \\
\hline Üç Faktörlü Yap1 & 199,67 & 41 & 4,87 & .95 & .92 & .96 & .095 \\
\hline Ölçütler & & & $\leq 5$ & $\geq .90$ & $\geq .90$ & $\geq .95$ & $\leq .08$
\end{tabular}

NFI: NormedFit Index, NNFI: Non-normed Fit Index, CFI: Comperative Fit Index, RMSEA: Root Mean Square Error of Approximation

Tablo 3'te görüldüğü üzere elde edilen DFA sonuçlarına göre tüm uyum indekslerinin kabul edilebilir düzeyde olduğu, sadece hata değerinin kabul edilen kritik değerin biraz üzerinde olduğu görülmektedir. Motivasyon ölçeğinde yer alan maddelerin üç boyutlu yapiyla kurulan modelin uygun olduğu sonucuna ulaşılmıştır (Bentler 1990).

\section{Kişilik Maddelerine İlişkin AFA ve DFA Sonuçları}

Açımlayıcı faktör analizi sonucunda kişilik ölçeğinin dışa dönük, deneyime açık, uyumlu, sorumlu ve nevrotik olmak üzere 5 alt boyuttan meydana geldiği belirlenmiştir. Örneklemde yer alan bireylerden elde edilen ölçüm sonucuna ilişkin iç tutarlılık anlamındaki güvenirlik katsayısı olan Cronbach alfa değerinin dişa dönük alt boyutu için .75; deneyime açık alt boyutu için .69; uyumlu alt boyutu için .68; sorumlu alt boyutu için .64 ve nevrotik alt boyutu için .55 olduğu belirlenmiştir. Kişilik ölçeğinin genelinden elde edilen cronbach alfa değeri ise .80 olarak hesaplanmıştır. Kişilik ölçeğinde yer alan maddelerin her bir boyutta aldıkları yük değerleri Tablo 4'te gösterilmiştir. 
Tablo 4. Kişilik Ölçeğinin Faktör Analizi Sonuçları

\begin{tabular}{|c|c|c|c|c|c|c|c|}
\hline Boyutlar & İfadeler & $\begin{array}{c}\text { Ortak } \\
\text { Varyans }\end{array}$ & F1 & F2 & F3 & F4 & F5 \\
\hline \multirow{4}{*}{ 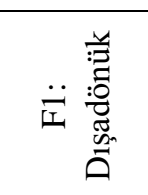 } & DIS1 & .669 & .755 & & & & \\
\hline & DIS2 & .587 & .739 & & & & \\
\hline & DIS5 & .624 & .736 & & & & \\
\hline & DIS3 & .678 & .714 & & & & \\
\hline \multirow{4}{*}{ 芒壱总 } & Den1 & .635 & & .769 & & & \\
\hline & Den2 & .696 & & .734 & & & \\
\hline & Den3 & .447 & & .638 & & & \\
\hline & Den4 & .409 & & .509 & & & \\
\hline \multirow{3}{*}{ 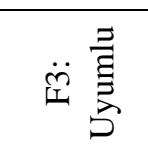 } & UY3 & .680 & & & .747 & & \\
\hline & UY2 & .676 & & & .701 & & \\
\hline & UY4 & .576 & & & .700 & & \\
\hline \multirow{3}{*}{ 芒首 } & Sor3 & .760 & & & & .842 & \\
\hline & Sor4 & .644 & & & & .661 & \\
\hline & Sor1 & .475 & & & & .518 & \\
\hline \multirow{4}{*}{ 莒 } & Nev2 & .728 & & & & & .833 \\
\hline & Nev3 & .636 & & & & & .767 \\
\hline & \multicolumn{2}{|c|}{ Öz değer } & 4,53 & 1,86 & 1,29 & 1,17 & 1,06 \\
\hline & \multicolumn{2}{|c|}{ Açcklanan Varyans } & 28,33 & 11,63 & 8,09 & 7,35 & 6,60 \\
\hline
\end{tabular}

Tablo 4 incelendiğinde 4 maddeden oluşan dışa dönük alt boyutunun öz değerinin 4,53 ve açıkladığ1 varyans miktarının \%28,33 olduğu belirlenmiştir. Toplam 4 maddeden oluşan deneyime açık alt boyutunun öz değerinin 1,86 ve açıkladığ 1 varyans miktarının \%11,63 olduğu belirlenmiştir. Toplam 3 maddeden oluşan uyumlu alt boyutunun öz değerinin 1,29 ve açıkladığ 1 varyans miktarının \%8,09 olduğu belirlenmiştir. Toplam 3 maddeden oluşan sorumlu alt boyutunun öz değerinin 1,17 ve açıkladığ 1 varyans miktarının \%7,35 olduğu belirlenmiştir. Toplam 2 maddeden oluşan nevrotik alt boyutunun öz değerinin 1,06 ve açıladığı varyans miktarının \%6,60 olduğu belirlenmiştir.

Toplam 16 madde ve 5 alt boyuta sahip kişilik ölçeği için kurulan ölçme modeline ilişkin uyum iyiliği sonuçları Tablo 5'te gösterilmiştir.

Tablo 5. Beş Boyutlu Kişilik Ölçme Modeline İlişkin Sonuçlar

\begin{tabular}{|l|c|c|c|c|c|c|c|}
\hline Model & $\chi^{\mathbf{2}}$ & $\mathrm{sd}$ & $\chi^{\mathbf{2}} / \mathrm{sd}$ & NFI & GFI & CFI & RMSEA \\
\hline Beş Faktörlü Yap1 & 297,29 & 94 & 3,16 & .91 & .92 & .93 & .073 \\
\hline Ölçütler & & & $\leq 5$ & $\geq .90$ & $\geq .90$ & $\geq .95$ & $\leq .08$ \\
\hline
\end{tabular}

NFI: Normed Fit Index, NNFI: Non-normed Fit Index, CFI: Comperative Fit Index, RMSEA: Root Mean Square Error of Approximation

Tablo 5'te görüldügü üzere elde edilen DFA sonuçlarına göre tüm uyum indekslerinin kabul edilebilir düzeyde olduğu, sadece CFI değerinin kabul edilen kritik değerin biraz altında olduğu görülmektedir. Böylece kişilik ölçeğinde yer alan 16 maddeyle kurulan beş boyutlu yapının model-veri uyumuna sahip olduğu sonucuna ulaşıllmıştır (Bentler 1990).

\section{Kalite Ölçeğine Yönelik Güvenirlik ve Geçerlilik Analizleri}

$\mathrm{Bu}$ işlemin ardından kalite ölçeğine ilişkin güvenirlik ve geçerlik analizleri yapılmıştır. Açımlayıcı 
faktör analizi sonucunda kalite ölçeğinin altı boyutlu bir yapıya sahip olduğu belirlenmiştir. Toplam 27 maddeden oluşan kalite ölçeğinin genelinden elde edilen cronbach alfa değeri 92 olarak hesaplanmıştır. Elde edilen bu sonuca göre ölçeğin güvenilir bir ölçme aracı olduğu sonucuna ulaşılmıştır. Bu işlemin ardından ölçeğin geçerliğine ilişkin analizler gerçekleştirilmiştir.

Tablo 6. Kalite Ölçeğin Döndürülmüş Faktör Analizi Sonuçları

\begin{tabular}{|c|c|c|c|c|c|c|c|c|}
\hline \multirow{2}{*}{ Boyutlar } & \multirow{2}{*}{$\begin{array}{l}\text { A. } \\
\text { Varyans }\end{array}$} & \multicolumn{7}{|c|}{ Bileşenler } \\
\hline & & & 1 & 2 & 3 & 4 & 5 & 6 \\
\hline \multirow{8}{*}{$\begin{array}{l}\text { Temizlik ve } \\
\text { Ulaşım }\end{array}$} & & Temizlik2 & ,715 & 224 & 115 &,- 046 & 423 &,- 038 \\
\hline & & Ulaşım2 & ,686 & ,027 & ,112 & ,095 &,- 009 & ,179 \\
\hline & & Temizlik1 & ,680 & 200 & 136 &,- 138 & ,352 & ,056 \\
\hline & 14,93 & Ulaşım6 & ,661 & ,175 & 087 & ,113 & ,050 & ,349 \\
\hline & & Ulaşım5 & ,654 & ,122 & ,146 & ,163 & ,038 & ,281 \\
\hline & & Temizlik3 & ,637 & ,194 & ,102 &,- 041 &, 540 & ,058 \\
\hline & & Ulaşım4 & ,624 & ,047 & ,206 & ,252 &,- 095 & ,223 \\
\hline & & Ulaşım3 & ,523 &,- 140 & 018 & ,319 & ,033 & ,066 \\
\hline \multirow{4}{*}{ Konaklama } & & Konaklama2 & 137 & ,867 & ,150 & 216 & ,060 & ,136 \\
\hline & 12,35 & Konaklama1 & ,170 & ,857 & ,195 & ,101 &, 040 & , 138 \\
\hline & & Konaklama3 & 222 & ,856 & ,120 & ,166 & ,044 & ,145 \\
\hline & & Konaklama4 &,- 071 & ,715 &,- 011 & ,487 & ,034 & ,071 \\
\hline \multirow{4}{*}{ Otantiklik } & & Otantik4 & ,229 & ,103 & ,818 & ,108 & ,135 & ,147 \\
\hline & 11,46 & Otantik3 & ,175 & ,073 & ,777 & ,122 & ,236 & ,121 \\
\hline & & Otantik2 & ,078 & ,109 & ,759 & ,094 & ,212 & ,026 \\
\hline & & Otantik5 & ,126 & ,196 & ,736 & ,067 & ,267 & 061 \\
\hline \multirow{4}{*}{ Fiyat } & 9,95 & Fiyat3 & ,283 & 146 &,- 072 & ,723 & ,163 & ,139 \\
\hline & & Fiyat2 & ,110 & ,134 & ,154 & ,722 &,- 014 & ,098 \\
\hline & & Fiyat1 &,- 052 & ,392 & ,150 & ,652 & ,125 & ,015 \\
\hline & & Fiyat4 & 119 & ,212 & ,134 & ,648 & ,092 &,- 137 \\
\hline \multirow{4}{*}{$\begin{array}{l}\text { Yemek ve } \\
\text { Misafirperverlik }\end{array}$} & & Yemek1 & ,060 & ,067 & ,343 & ,013 & ,726 & ,147 \\
\hline & & Yemek2 &,- 008 & 027 & ,378 & ,057 & ,646 & ,293 \\
\hline & 9,40 & Misafirperver & 099 &,- 113 & ,284 & ,385 &, 547 & ,082 \\
\hline & & Misafirperver & ,199 & ,053 & ,148 & ,202 & ,507 & , 160 \\
\hline \multirow{3}{*}{ Etkinlik } & & Etkinlik1 & ,350 & ,188 & 107 & ,020 & ,169 & ,823 \\
\hline & 8,26 & Etkinlik2 & ,314 & ,182 & 091 & ,017 & ,219 & ,815 \\
\hline & & Alışveriş1 & ,255 & ,128 & ,224 & ,084 & ,321 & ,550 \\
\hline
\end{tabular}

Tablo 6 incelendiğinde her bir faktör için açıklanan varyans miktarları ve faktör yükleri gösterilmiştir. Temizlik ve Ulaşım boyutunu oluşturan 8 maddenin faktör yük değerlerinin. 72 ile. 52 arasında değiştiği görülmektedir. Konaklama boyutunda yer alan 4 maddenin faktör yük değerlerinin. 87 ile. 72 aralı̆̆ında; Otantik boyutunda yer alan maddenin faktör yük değerlerinin. 82 ile. 74 aralığında; Fiyat boyutunda yer alan maddenin faktör yük değerlerinin. 72 ile. 65 aralığında; Yemek ve Misafirperverlik boyutunda yer alan maddenin faktör yük değerlerinin. 73 ile. 51 aralığında ve son olarak Etkinlik boyutunda yer alan maddenin faktör yük değerlerinin. 82 ile. 55 aralığında olduğu belirlenmiştir.

Elde edilen bu sonuca göre 6 boyutlu ölçekte yer alan maddelerin açıkladığı varyans miktarı toplamı \%66,38 olarak belirlenmiştir. Çalışmanın amacına bağlı olarak Kaliteyi oluşturan boyutlar- 
dan elde edilen puanların toplanabilir olup olmadığını belirlemek amacıyla hem alt boyutların kendi arasında hem de her bir alt boyutun ölçeğin tamamı ile aralarındaki ilişkileri belirlemek amacıyla korelasyon analizi uygulanmış ve analiz sonuçları Tablo 7'de gösterilmiştir.

Tablo 7. Toplam Kalite ve Alt Boyutlar Arasındaki İlişkiler

\begin{tabular}{|c|c|c|c|c|c|c|c|}
\hline Boyutlar & 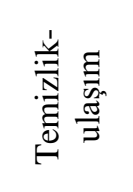 & 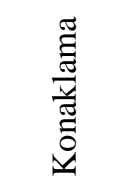 & $\begin{array}{l}\text { 泀 } \\
\text { 营 }\end{array}$ & $\stackrel{\vec{\pi}}{\stackrel{\pi}{\mid c}}$ & 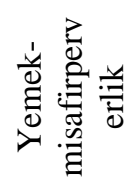 & 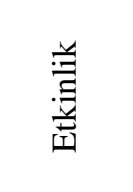 & 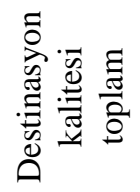 \\
\hline Temizlik-ulaşım & 1 & & & & & & \\
\hline Konaklama & ,340(**) & 1 & & & & & \\
\hline Otantik & ,399(**) & ,291(**) & 1 & & & & \\
\hline Fiyat & ,370(**) & ,495(**) & ,248(**) & 1 & & & \\
\hline Yemek-misafirperverlik & ,441(**) & ,254(**) &, $551(* *)$ & ,315(**) & 1 & & \\
\hline Etkinlik &, $595(* *)$ & ,403(**) & ,355(**) & ,363(**) & $402(* *)$ & 1 & \\
\hline Toplam Destinasyon Kalitesi & ,798(**) & ,706(**) & ,666(**) & ,657(**) &, $648(* *)$ &, $710(* *)$ & 1 \\
\hline
\end{tabular}

** Korelasyon 0.01 düzeyinde anlamlı. * Korelasyon 0.05 düzeyinde anlamlı

Tablo 7 incelendiğinde alt boyutlar arasındaki korelasyon katsayıları .29 ile .59 arasında iken alt boyutların toplam kalite boyutu ile arasındaki ilişkiyi gösteren korelasyon katsayıları .64 ile .79 arasında değişmektedir. Elde edilen bu sonuç alt boyutların toplam kalite ile istatistiksel olarak anlamlı ve yüksek düzeyde bir ilişkiyi sahip olduğunu göstermektedir. Buna göre ölçeğin toplam puanı anlamlı olduğu gibi karar verme sürecinde de kullanılabilecektir (Erkuş 2014, 126). $\mathrm{Bu}$ işlemlerin ardından açımlayıcı faktör analizi sonucunda elde edilen faktör yapısını tanımlayan ölçme modelinin verilerle uyum sağlayıp sağlamadığını incelemek amacıyla doğrulayıcı faktör analizi uygulanmıştır. Analize ilişkin bulgular doğrulayıcı faktör analizi başlığı altında verilmiştir. Son olarak toplam 27 madde ve 6 alt boyutlu bir yapıya sahip kalite ölçeği için kurulan ölçme modeline ilişkin uyum iyiliği sonuçları Tablo 8'de gösterilmiştir.

Tablo 8. Tek Boyutlu Kalite Ölçme Modeline İlişkin Sonuçlar

\begin{tabular}{|l|c|c|c|c|c|c|c|}
\hline Model & $\chi^{2}$ & sd & $\chi^{2} /$ sd & NFI & GFI & CFI & RMSEA \\
\hline Altı Faktörlü Yap1 & 998,12 & 309 & 3,23 & .94 & .95 & .95 & .075 \\
\hline Ölçütler & & & $\leq 5$ & $\geq .90$ & $\geq .90$ & $\geq .95$ & $\leq .08$ \\
\hline
\end{tabular}

NFI: Normed Fit Index, NNFI: Non-normed Fit Index, CFI: Comperative Fit Index, RMSEA: Root Mean Square Error of Approximation

Tablo 8'de görüldüğü üzere elde edilen DFA sonuçlarına göre tüm uyum indekslerinin kabul edilebilir düzeyde olduğu, sadece RMSEA değerinin kabul edilen kritik değerin altında ve benzer şekilde X2/sd oranının kritik değeri aşmadığ 1 görülmektedir. Böylece kalite ölçeğinde yer alan 27 maddeyle kurulan altı boyutlu yapının mükemmel bir model-veri uyumuna sahip olduğu sonucuna ulaşılmıştır (Bentler 1990).

\section{Bulgular}

Katılımcılara yönelik istatistiklere baktığımızda, çoğunun erkek $(\% 53,5)$, bekar (\%76), üniversite mezunu (\%56) oldukları görülmektedir. Ayrıca seyahat deneyimlerine ilişkin olarak bireysel $(\% 51,3)$ ve paket turla $(\% 48,7)$ geldikleri ve daha çok otel işletmeleri $(\% 29,8)$ ile pansiyon, misafirhane $(\% 49,3)$ gibi konaklama işletmelerini tercih ettikleri, aynı zamanda \%20'sinin akraba-arkadaş evlerinde kaldıkları görülmektedir. Katılımcıların çoğunlukla 1-3 (\%68) gece 
kaldıkları ortaya çıkmıştır. Ayrıca \%39,5'inin ilk defa geldiği tespit edilmiştir. Yaş değişkeni kategorik olarak değil açık uçlu olarak sorulmuştur. Katılımcıların en düşük 18 ve en yüksek 61 yaşında oldukları ve yaş ortalamalarının 26,54 olduğu belirlenmiştir. Ayrıca katılımcıların gelirlerinin ortalaması 2000 Türk Lirası olduğu ve yaptıkları harcamanın ortalaması 598,00 Türk Lirası olduğu tespit edilmiştir.

Katılımcıların geldikleri destinasyona ilişkin nereden bilgi aldıklarına bakıldığında en fazla internet kaynaklarından $(\% 47,8)$ olmak üzere, en fazla aile ve arkadaş tavsiyelerinden $(\% 41,3)$ ve acentalardan $(\% 13,5)$ bilgi edindikleri ortaya çıkmıştır.

Aşağıda kişilik, seyahat motivasyonu ve algılanan destinasyon kalitesine yönelik katılımc1ların verdikleri cevapların ortalama ve Standart Sapma değerleri verilmiştir.

Tablo 9. Kişilik’e Yönelik Tanımlayıcı İstatistikler

\begin{tabular}{|l|c|c|}
\hline Ölçekler & Ortalama & Std.Sapma \\
\hline Kişilik Toplam & 3,89 &, 446 \\
\hline Dışa dönük & 3,95 &, 791 \\
\hline DIS1: Dışa dönük biriyim. & 4,10 &, 97 \\
\hline DIS2: Çekingen biriyim. ${ }^{*}$ & 3,77 & 1,23 \\
\hline DIS3: Enerjik biriyim. & 4,07 &, 83 \\
\hline DIS5: Konuşkan biriyim. & 3,87 & 1,10 \\
\hline Uyumlu & 4,29 &, 657 \\
\hline UY2: Hoşgörülü biriyim. & 4,21 &, 85 \\
\hline UY3: Saygıll, düşünceli biriyim. & 4,32 &, 77 \\
\hline UY4: Yardımsever biriyim. & 4,35 &, 88 \\
\hline Nevrotik & 2,53 & 1,00 \\
\hline Nev2: Bunalımlı biriyim. & 2,65 & 1,27 \\
\hline Nev3: Sinirli biriyim. & 2,42 & 1,15 \\
\hline Deneyime açı & 4,08 &, 662 \\
\hline Den1: Orjinal biriyim. & 3,95 &, 89 \\
\hline Den2: Yenilikçi biriyim. & 4,28 &, 78 \\
\hline Den3: İlginç biriyim & 4,05 & 1,03 \\
\hline Den4: Hayal gücü kuvvetli biriyim. & 4,08 &, 94 \\
\hline Sorumlu & 4,07 &, 710 \\
\hline Sor1: Planları takip eden biriyim. & 3,95 &, 94 \\
\hline Sor3: İ̧imi mükemmel yaparım. & 4,01 & 1,01 \\
\hline Sor4: Verimli biriyim. & 4,26 &, 82 \\
\hline
\end{tabular}

Katılımcıların sahip oldukları kişilik özellikleri ortalamalarına bakıldığın kişilik boyutlarından nevrotik kişilik özelliklerinin çok düşük (Ort. 2,53-ss. 1,27), diğer boyutların ise ortalamalarının dördün üzerinde olduğu tespit edilmiştir.

Tablo 10. Seyahat Motivasyonlarına Yönelik Tanımlayıcı İstatistikler

\begin{tabular}{|l|c|c|}
\hline Ölçek & Ortalama & Std.Sapma \\
\hline Seyahat Motivasyonları Toplam & 3,81 &, 792 \\
\hline Kültür & 4,20 &, 853 \\
\hline Kültür1: Yeni yer bilgimi arttırmak & 4,17 &, 98 \\
\hline Kültür2: Yerel halkla tanışmak & 4,11 & 1,02 \\
\hline
\end{tabular}




\begin{tabular}{|l|c|c|}
\hline Kültür3: Tarihi / kültürel yerleri ziyaret etmek & 4,33 &, 98 \\
\hline Eğlence & 3,55 &, 991 \\
\hline Eğlence1: Macera aramak & 3,38 & 1,30 \\
\hline Eğlence2: Eğlenmek & 3,57 & 1,24 \\
\hline Eğlence3: Evden uzaklaşmak için & 3,73 & 1,18 \\
\hline Eğlence4: Diğer turistlerle kaynaşmak & 3,55 & 1,37 \\
\hline Dinlenme & 3,79 &, 989 \\
\hline Dinlenme2: İyi havanın tadını çıkarmak için & 3,88 & 1,13 \\
\hline Dinlenme3: Rahatlamak & 3,96 & 1,11 \\
\hline Dİnlenme1: Duygusal ve fiziksel olarak yenilenmek & 3,91 & 1,13 \\
\hline Dinlenme4: İçten ilgilenen insanlarla vakit geçirmek & 3,43 & 1,34 \\
\hline
\end{tabular}

Katılımcıların bölgeye daha çok destinasyon çekim boyutlarından kültürel motivasyon için geldikleri (Ort.4,20, ss. ,85), Bunun yanında dinlenme (Ort. 3,79, ss. ,98) ve eğlence (Ort. 3,55, ss. ,99) gibi itici boyutlarında bireyleri destinasyona gelme konusunda motive ettikleri tespit edilmiştir.

Tablo 11. Destinasyon Kalitesine Yönelik Tanımlayıcı İstatistikler

\begin{tabular}{|l|c|c|}
\hline Ölçek & Ortalama & Std.Sapma \\
\hline Destinasyon Kalitesi Toplam & 3,72 & 0,64 \\
\hline Temizlik-Ulaşım & 3,42 & 0,80 \\
\hline Temizlik1: Şehrin temizliği & 3,34 & 1,13 \\
\hline Temizlik2: İşletmelerin hijyen durumu & 3,40 & 1,09 \\
\hline Temizlik3: Yerel halkın-Çalışanların temizliği & 3,41 & 1,06 \\
\hline Ulaşım2: Cadde, yol, tarihi yer işaret ve levhaları & 3,30 & 1,40 \\
\hline Ulaşım3: Trafik yoğunluğu & 3,21 & 1,26 \\
\hline Ulaşım4: Şehirlerarası otobüs hizmetleri & 3,40 & 1,08 \\
\hline Ulaşım5: Turistik yerlere ulaşım imkânı & 3,54 & 1,07 \\
\hline Ulaşım6: Turist bilgilendirme broşürleri-dergileri & 3,34 & 1,16 \\
\hline Konaklama & 3,36 & 1,39 \\
\hline Konaklama1: Konaklama işletmesinin hizmetleri & 3,40 & 1,52 \\
\hline Konaklama2: Konaklama işletmesi çalışanlarının & 3,55 & 1,51 \\
\hline Konaklama3: Konaklama işletmesinin konforu & 3,42 & 1,49 \\
\hline Konaklama4: Konaklama işletmesinin fiyatı & 3,11 & 1,67 \\
\hline Otantik & 4,33 & 0,72 \\
\hline Otantik2: Doğal görüntü ve manzara & 4,39 &, 82 \\
\hline Otantik3: Tarihi binaların mimarisi & 4,39 &, 82 \\
\hline Otantik4: İnsanlık tarihini, medeniyetleri hissetme & 4,34 &, 87 \\
\hline Otantik5: Gezdiğim yerlerin otantik atmosferi & 4,31 &, 90 \\
\hline Yemek ve Misafirperverlik & 4,17 & 0,69 \\
\hline Misafirperver1: Yerel halkın konukseverliği & 4,18 &, 91 \\
\hline Misafirperver2: Esnafların turistlere yönelik tutumu & 3,97 & 1,04 \\
\hline Yemek1: Yeme-içme lezzeti & 4,22 &, 88 \\
\hline Yemek2: Yiyecek içeceklerin çeşitliliği & 4,18 &, 89 \\
\hline Etkinlik & 3,31 & 1,24 \\
\hline Etkinlik1: Etkinliklerin yeterliliği & 3,17 & 1,45 \\
\hline
\end{tabular}




\begin{tabular}{|l|c|c|}
\hline Ölçek & Ortalama & Std.Sapma \\
\hline Etkinlik2: Etkinliklerin çeşitliliği & 3,23 & 1,46 \\
\hline Alışveriş1: Alışveriş imkânları & 3,54 & 1,27 \\
\hline Fiyat & 3,26 & 1,08 \\
\hline Fiyat1: Yeme-içme fiyatları & 3,42 & 1,39 \\
\hline Fiyat2: Hediyelik eşya fiyatları & 3,21 & 1,33 \\
\hline Fiyat3: Etkinlik/eğlence fiyatları & 3,06 & 1,51 \\
\hline Fiyat4: Tatil için yaptığım toplam harcama & 3,37 & 1,41 \\
\hline
\end{tabular}

Katılımcıların geldikleri destinasyona yönelik kalite algılarının genel olarak (Ort. 3,72, ss.0,64) iyi düzeyde olduğu tespit edilmiştir. Ancak fiyat kalitesi (Ort. 3,26, ss.1,08), etkinlik kalitesi (Ort. 3,31, ss.1,24), konaklama kalitesi (Ort. 3,36, ss. 1,39), temizlik ve ulaşım kalitesi (Ort. 3,42, ss.0,80) boyutlarının genel kalite algısının (Ort. 3,72) altında ve likert ölçekte orta düzeyde oldukları ortaya çıkmıştır. Ancak otantiklik kalitesi (Ort. 4,33, ss.0,72) ve yemek-misafirperverlik kalitesi (Ort. 4,17, ss.0,69) boyutlarına ilişkin algılarının genel kalite algısının üstünde ve liket ölçekte yaklaşık olarak çok iyi seçeneğine denk gelmektedir.

\section{Lojistik Regresyon Analizi Sonuçları}

Lojistik regresyon analizinde ilk olarak örneklem büyüklüğünün analiz için uygunluğu test eden analiz sonucu verilmektedir. Toplam 400 katılımcı ile gerçekleştirilen çalışmada kayıp değerlerin olmadığ 1 belirlenmiştir. Analize dâhil edilen demografik değişkenler ile bunların nasıl kodlandığı Tablo 12'de gösterilmiştir.

Tablo 12 incelendiğinde analize dâhil edilen değişkenlerden eğitim durumu, medeni durum ve cinsiyet değişkenlerinin kategorik olduğu ve modelde bu durumun dikkate alındığ 1 görülmektedir. Lojistik regresyon analizinde bağımsız değişkenlerin modele dahil edilmeden katılımcıların düşük ve yüksek destinasyon kalite alg1 düzeyine sahip olacak şekilde sınıflama

\begin{tabular}{|l|c|c|c|c|c|}
\hline \multicolumn{6}{|c|}{ Tablo 12. Kategorik Değişkenler ve Düzeyleri } \\
\hline & & Frekans & \multicolumn{3}{|c|}{ Parametre kodları } \\
\hline & & $(1)$ & $(2)$ & $(3)$ \\
\hline Eğitim & İlköğretim & 1 &, 000 &, 000 &, 000 \\
\hline & Lise & 39 & 1,000 &, 000 &, 000 \\
\hline & Üniversite & 110 &, 000 & 1,000 &, 000 \\
\hline & Lisansüstü & 66 &, 000 &, 000 & 1,000 \\
\hline Medeni & Evli & 53 &, 000 & & \\
\hline & Bekâr & 163 & 1,000 & & \\
\hline Cinsiyet & Erkek & 98 &, 000 & & \\
\hline & Kadın & 118 & 1,000 & & \\
\hline
\end{tabular}
sonuçları Tablo 13’te gösterilmiştir.

Tablo 13. Başlangıçtaki Sınıflama Sonuçları

\begin{tabular}{|l|c|c|c|}
\hline & \multicolumn{3}{|c|}{ Destinasyon Kalite Algısı } \\
\hline & Düşük (0) & Yüksek (1) & Doğru Sınıflama (\%) \\
\hline Düşük (0) & 0 & 104 & 0,00 \\
\hline Yüksek (1) & 0 & 112 & 100,00 \\
\hline Toplam sınıflama & 398 & 0 & 51,90 \\
\hline
\end{tabular}

Tablo 13 incelendiğinde analize başlamadan önce kalite algısı düşük olan 104 katılımcının program tarafından "düşük" algı düzeyinde ve algı düzeyi yüksek olan 112 katılımcının ise program tarafından "yüksek" olarak sınıflandığı belirlenmiştir. Elde edilen bu sonuca göre analiz öncesinde programın doğru sınıflama oranının \%51,90 olduğu belirlenmiştir. Bir sonraki aşamada 
yordayıcı değişkenlerin modele nasıl bir etkide bulunduğunu belirlemek amaciyla elde edilen başlangıç bloğunda yer alan değişkenlerin anlamlılık değerleri ile belirlenen serbestlik derecesindeki yük değerleri Tablo 14’te gösterilmiştir.

Tablo 14. Başlangıç Modeline Yönelik Analiz Sonuçları

\begin{tabular}{|l|l|l|c|c|c|}
\hline \multicolumn{2}{|l}{} & Skorlar & df & p \\
\hline Adım 0 & Değişkenler & Motivkültür & 12,074 & 1 &, 001 \\
\hline & & Motiveğlence & 20,693 & 1 &, 000 \\
\hline & & Motivdinlenme & 13,917 & 1 &, 000 \\
\hline & & Dişa dönük & 12,009 & 1 &, 001 \\
\hline & Uyumlu & 2,690 & 1 &, 101 \\
\hline & & Nevrotik & 7,327 & 1 &, 007 \\
\hline & & Deneyime açık & 5,314 & 1 &, 021 \\
\hline & Sorumluluk &, 028 & 1 &, 868 \\
\hline & & Yaş & 2,473 & 1 &, 116 \\
\hline & Cinsiyet (1) & 2,530 & 1 &, 112 \\
\hline & Medeni durum (1) & 4,207 & 1 &, 040 \\
\hline & & Eğitim & 13,159 & 3 &, 004 \\
\hline & Eğitim (1) & 1,082 & 1 &, 298 \\
\hline & & Eğitim (2) &, 076 & 1 &, 783 \\
\hline & & Eğitim (3) & 8,918 & 1 &, 003 \\
\hline & & G. Doğu'ya geliş sayıs1 & 1,824 & 1 &, 177 \\
\hline & & Geceleme sayis1 & 9,306 & 1 &, 002 \\
\hline & & & 52,740 & 16 &, 000 \\
\hline
\end{tabular}

Tablo 14 incelendiğinde katılımcıların seyahat motivasyonu alt boyutlarından kültür, eğlence ve dinleme ile kişilik türlerinden dişadönük, nevrotik ve deneyime açık değişkenlerinin başlangıç modelinde anlamlı bir etkiye sahip olacağı belirlenmiştir. Bunun yanında demografik özelliklerden medeni durum ile eğitim düzeyinin, seyahat deneyiminden geceleme sayısının başlangıç modelinde anlamlı bir etkiye sahip olacağı belirlenmiştir $(\mathrm{p}<.05)$. Bunun yanında çalışma kapsamında ele alınan değişkenler ile kurulan modelin bir bütün olarak anlamlı olduğu görülmektedir $(\mathrm{p}=.000)$. Bu aşamadan sonra yapılması gereken yordayıcı değişkenleri modele dâhil ettiğimizde her bir değişkenin nasıl ve ne düzeyde bir etkiye sahip olacağının belirlenmesidir. Bağımsız değişkenlerin modele dâhil edildikten sonraki ikinci aşamada (Block1) modelin ne kadar iyi çalıştığına ilişkin analiz sonuçları Tablo 15'de gösterilmiştir.

Tablo 15. Model Katsayılarının Omnibus Testi

\begin{tabular}{|l|c|c|c|c|}
\hline & & Chi-square & df & Sig. \\
\hline \multirow{3}{*}{ Step 1 } & Step & 59,83 & 16 &, 000 \\
\cline { 2 - 5 } & Block & 59,83 & 16 &, 000 \\
\cline { 2 - 5 } & Model & 59,83 & 16 &, 000 \\
\hline
\end{tabular}

Tablo 15’te verilen Omnibus testi sonucunda hiçbir değişken eklenmeden elde edilen başlangıç modeli ile yordayıcı değişkenlerin analize dâhil edilmesinin ardından elde edilen modelin istatistiksel olarak anlamlı olduğu belirlenmiştir $(\chi 2=59,83 ; \mathrm{df}=16 ; \mathrm{p}<.05)$. Model uyum indeksi olarak da bilinen bu değerlere göre araştırmacılar tarafından önerilen Destinasyon Kalite Algısının yordanmasına ilişkin modelin iyi bir uyuma sahip olduğu görülmektedir (Pallant, 2005). Model tarafından bağımlı değişkendeki değişimin bağımsız değişkenler tarafından ne 
kadar açıklandığını gösteren R2 istatistiklerinden "The Cox ve Snall R Square" ve "Nagelkerke $R$ Square” değerleri Tablo 16'da gösterilmiştir.

Tablo 16. Modelin Yordayıcı Değişkenler Tarafından Açıklanma Oranları

\begin{tabular}{|l|c|c|c|}
\hline Step & -2 Loglikelihood & CoxveSnell R Square & Nagelkerke R Square \\
\hline 1 & $239,314^{(\mathrm{a})}$ &, 242 &, 323 \\
\hline
\end{tabular}

a Estimation terminated at iteration number 20 because maximum iterations has been reached.

The Cox ve Snall R2 değerine göre bağımlı değişkenin yordayıcı değişkenler tarafından açıklanma oranı 0,242 olarak belirlenmiştir. Buna göre kalite algısının \%24,20'si çalışma kapsamında ele alınan değişkenler tarafından açıklanmaktadır. Bunun yanında bir diğer açıklanan varyans oranını gösteren istatistik olan Nagelkerke R2 değerine göre bağımlı değişkenin yordayıcı değişkenler tarafından açıklanma oranı 0,323 olarak belirlenmiştir. Bu bulguya göre destinasyon kalite algısının \%32,30'u çalışma kapsamında ele alınan değişkenler tarafından açıklandığı görülmektedir. Modelin güvenilir bir model olup olmadığına ilişkin Hosmer ve Lemeshow testi sonucunda 8 serbestlik derecesinde $\chi 2$ değeri 5,59 olarak belirlenmiş ve bu değer kritik değerden büyük olması sebebiyle $(\mathrm{p}=.544)$ modelin uyumsuzluk göstermediği sonucuna ulaşılmıştır. Başka bir ifadeyle önerilen model çalışma kapsamında ele alınan veriler yardımıyla desteklenmektedir. Lojistik regresyon, çoklu regresyonda elde edilen R2'ye göre oldukça küçük değerler alma eğiliminde olduğundan 0,20-0,40 arasındaki bir R2 değerinin yüksek olduğu söylenebilir (Şenel ve Alatlı 2014, 41). Katılımcıların kalite alg1 düzeyleri bakımından sınıflandıkları regresyon modelinde yordayıcı değişkenlerin modele dâhil edildikten sonra program tarafından katılımcıların "düşük" ve "yüksek" destinasyon kalite algısına sahip şeklinde sinıflama sonuçları Tablo 17'de gösterilmiştir.

Tablo 17. Oluşturulan Modeldeki Sınıflama Sonuçları

\begin{tabular}{|l|c|c|c|}
\hline & \multicolumn{3}{|c|}{ Destinasyon Kalite Algıs1 } \\
\hline & Düşük (0) & Yüksek (1) & Doğru Sinıflama (\%) \\
\hline Düşük (0) & 71 & 33 & 68,30 \\
\hline Yüksek (1) & 30 & 82 & 73,20 \\
\hline Toplam sinıflama & 101 & 115 & 70,80 \\
\hline
\end{tabular}

Tablo 17 incelendiğinde analize başlamadan önce kalite algısı düşük olan 104 bireyin 71'inin program tarafından "düşük” olarak doğru sinıflanırken 33 katılımcının "yüksek" olarak yanlış sınıflandığ1 görülmektedir. Benzer şekilde kalite algısı yüksek olan 112 katılımcıdan 82'si "yüksek" olarak doğru sinıflanırken 30 tanesinin "düşük” şeklinde yanlış sinıflandığ 1 belirlenmiştir. Elde edilen bu sonuca göre modele yordayıcı değişkenlerin dâhil edilmesinin ardından programın doğru sınıflama oranının \%70,80 olduğu belirlenmiştir. Çalışmada son olarak yordayıcı değişkenlerin her birinin modeldeki önem düzeyi ve regresyon modelindeki katkısını gösteren analiz sonuçlarıdır. Oluşturulan modele ilişkin yordayıcı değişkenlerin regresyon denklemindeki katsayı değerleri ile bu katsayıların anlamlılık ve güven aralıkları Tablo 18'de gösterilmiştir. Tablo 18 incelendiğinde çalışma kapsamında ele alınan değişkenlerden anlamlılık (p) değeri 0.05 'ten küçük olanların destinasyon kalite algısını yordanmasına ilişkin önerilen modele anlamlı bir katkıda bulundukları sonucuna ulaşılmaktadır. 
Tablo 18. Oluşturulan Modeldeki Yordayıcı Değişkenlerin Değerleri

\begin{tabular}{|l|l|c|c|c|c|c|c|}
\hline \multicolumn{2}{|l|}{} & B & S.E. & Wald & df & Sig. & Exp(B) \\
\hline Adım 1(a) & Motivkültür &, 066 &, 255 &, 066 & 1 &, 797 & 1,068 \\
\hline & Motiveğlence &, 382 &, 234 & 2,664 & 1 &, 103 & 1,466 \\
\hline & Motivdinlenme &, 326 &, 222 & 2,143 & 1 &, 143 & 1,385 \\
\hline & Dişa dönük &, 665 &, 222 & 8,938 & 1 &, 003 & 1,944 \\
\hline & Uyumlu &, 231 &, 319 &, 525 & 1 &, 469 & 1,260 \\
\hline & Nevrotik &,- 316 &, 171 & 3,442 & 1 &, 064 &, 729 \\
\hline & Deneyime açık &, 204 &, 306 &, 446 & 1 &, 504 & 1,226 \\
\hline & Sorumluluk &,- 393 &, 277 & 2,008 & 1 &, 157 &, 675 \\
\hline & Yaş &, 043 &, 026 & 2,771 & 1 &, 096 & 1,044 \\
\hline & Cinsiyet (1) &, 575 &, 325 & 3,116 & 1 &, 078 & 1,776 \\
\hline & Medeni durum (1) &,- 323 &, 478 &, 458 & 1 &, 498 &, 724 \\
\hline & Eğitim & & & 4,872 & 3 &, 181 & \\
\hline & Eğitim (1) & $-19,828$ & 40192,970 &, 000 & 1 & 1,000 &, 000 \\
\hline & Eğitim (2) &, 672 &, 519 & 1,677 & 1 &, 195 & 1,957 \\
\hline & Eğitim (3) &, 916 &, 415 & 4,871 & 1 &, 027 & 2,500 \\
\hline & G. Doğu'ya geliş sayıs1 &,- 149 &, 104 & 2,061 & 1 &, 151 &, 861 \\
\hline & Geceleme sayıs1 &,- 405 &, 209 & 3,748 & 1 &, 043 &, 667 \\
\hline & Constant & $-5,870$ & 2,101 & 7,805 & 1 &, 005 &, 003 \\
\hline
\end{tabular}

Buna göre katılımcıların kişilik türlerinden dişa dönük kişilik türü $(\beta=.67, p=.003)$, eğitim düzeyi değişkeninden yüksek lisans/doktora mezunu olma $(\beta=.92, p=.027)$ ve geceleme sayıs1 $(\beta=-.41, p=.043)$ değişkenlerinin modelde anlamlı bir etkiye sahip oldukları görülmektedir. Anlamlı bir etkiye sahip olduğu belirlenen yordayıcı değişkenlerin $\beta$ değerlerinin pozitif veya negatif olması ilişkinin yönünü, katsayının sayısal değeri ise ilişkinin şiddetini göstermektedir. Buna göre modeldeki en büyük katkıyı eğitim değişkeninin ve sonrasında sırasıyla dışa dönük kişilik tipi değişkenleri pozitif yönde bir etkiye sahip iken geceleme sayısı değişkeni $(\beta=-0,405)$ negatif yönde ve istatistiksel olarak anlamlı bir etkiye sahip olduğu belirlenmiştir. Tablonun son sütununda yer alan ve Odds oranı olarak bilinen $\operatorname{Exp(B)}$ değerleri bağımsız değişkendeki bir birimlik artışın bağımlı değişkende ne kadarlık bir artışa sebep olacağını göstermektedir. Buna göre eğitim düzeyindeki bir birimlik artış onların kalite algısında 2,50 puanlık bir artışa sebep olacaktır. Geceleme sayısındaki bir birimlik artış kalite algısında 0,67 puanlık bir azalışa ve dışa dönük kişilik tipindeki bir birimlik farklılık kalite algısında 1,94 puanlık bir farklılığa sebep olacağı görülmektedir.

\section{Sonuç, Tartıșma ve Öneriler}

Bu makalede turistlerin destinasyon kalite algısında seyahat motivasyonu, kişilik özellikleri, demografik özelliklerin yordama gücü incelenmiştir. Güneydoğu illerinden Şanlıurfa ve Gaziantep’i ziyaret eden yerli turistlere uygulanan anket ile toplanan verilere lojistik regresyon analizi uygulanmıştır. Turistlerin algıladıkları destinasyon kalitesinde eğitim düzeyinin, kişiliğin ve destinasyonda geceleme sayısının etkili olduğu, ancak seyahat motivasyonu, yaş, medeni durum, destinasyona geliş sayısı gibi değişkenlerin etkili olmadığı tespit edilmiştir

Betimsel istatistiklerin sonucunda katılımcıların uyumlu, dışa dönük, deneyime açık ve sorumlu kişilik özelliklerine sahip oldukları ve nevrotik kişilik özelliğine sahip olmadıkları ortaya çıkmıştır. Kültür turizmi destinasyonlarına gelen turistlerin deneyime açık, uyumlu ve 
dışa dönük kişilerin olması beklenir. Çünkü kültür destinasyonları turistlerin farklı yaşayışları, kültürleri görmek ve öğrenmek için geldikleri destinasyonlardır. Dolayısı ile yerel halkla etkileşimleri olan ve onları tanımaya çalışan kişilerin daha çok tercih ettiği destinasyonlardır. Aynı şekilde kültür destinasyonu olarak bilinen araştırma alanına gelen turistlerin daha çok kültürel motivler için gelmiş olmaları beklenen bir sonuçtur.

Katılımcıların seyahat motivasyonlarına bakıldığında ağırlıklı olarak kültürel unsurlar için geldikleri, daha sonra eğlence ve dinlenme amacı ile geldikleri ortaya çıkmıştır. Bu sonuç Barakazı ve Karapınar (2015) tarafından da saptanmıştır. Ayrıca katılımcıların destinasyon kalitesine yönelik algılarında en fazla kaliteli gördükleri unsurların destinasyonun otantik yapısı ve yemek-misafirperverlik olduğu belirlenmiştir. Bunların dışında ulaşım-temizlik, konaklama, etkinlik ve fiyat unsurlarına yönelik algılarının orta düzeyde olduğu görülmektedir. Destinasyonun sahip olduğu mimari dokusu ve farklı medeniyetlerden kalan kültürel yapılar otantikliği yüksek düzeyde kaliteli bulmalarında rol oynadığı söylenebilir. Nitekim, Birdir, Karakan ve Çolak (2016) Gaziantep'e yönelik yaptıkları içerik analizi sonucunda, tarihi unsurları destinasyonun en güçlü yönü olarak vurgulamışlardır. Ayrıca yemek çeşitliliği ve lezzeti bakımından gastronomi şehri olarak tescillenen Gaziantep ve benzer özellikler gösteren Şanlıurfa'nın yemek ve misafirperverlik konusunda yüksek düzeyde algılanmış olması beklenen bir sonuçtur.

Araştırma sonucunda algılanan destinasyon kalitesinin düşük veya yüksek olarak algılanmasında destinasyonda kişilik özelliklerinden dışa dönüklügün, etkili olduğu ortaya çıkmıştır. Gountas ve Shaw (2001) kişilik ile hizmet kalitesi algısının ilişkili olduğunu ortaya koymuşlardır. Ayrıca destinasyon kalitesi ile yüksek ilişkisi olan müşteri/turist memnuniyetinde de dişa dönüklügün etkili olduğunu ortaya koyan çalışmalar (Mooradian ve Olver 1997; Tan vd. 2004; Matzler vd. 2005; Faullant vd. 2011; Jani ve Han 2014) mevcuttur. Ancak literatürde nevrotik kişilik özelliklerinin de negatif duyguları oluşturmasından dolayı, memnuniyeti dolayısı ile kaliteyi negatif etkilediği bulguları (Tan vd. 2004; Faullant vd. 2011) çalışmamız tarafından desteklenmemiştir.

Turizm destinasyonlarını ziyaret eden turistlerin kişilik özelliklerine göre beklenti ve kalite algıları farklı olmaktadır. Bazı turistlerin beklentileri düşük iken bazılarının yüksek olabilmektedir, bazı turistler mükemmel hizmet isterken bazıları ortalama bir hizmeti yeterli görebilmektedir. Bu durumda destinasyona gelen bir turiste verilen hizmet mükemmel olsa bile, duygusal veya psikolojik olarak sorunlu bir turist olması halinde o destinasyondan memnun olamayabilir (Tan vd. 2004, 288). Ayrıca insanlarla uyumlu olan, sabırlı ve hoşgörülü turistlerin bazı ufak problemleri görmezden gelebilmeleri ile mükemmel bir hizmet almamış olsalar bile memnuniyetlerinin yüksek olabileceği bilinmektedir. Ek olarak farklı yaşam tarzlarına ve yemeklere alışkın olan dışa dönük, deneyime açık kişiler, bir destinasyona gittiğinde yemek konusunda veya geldiği destinasyon kültürüne adaptasyon konusunda fazla sorun yaşamayacaktır. Tersi bir durumda, deneyime açık olmayan turistlerin kültür şoku ile karşılaşma ihtimalleri daha yüksek olmaktadır. Sonuç olarak bazen destinasyonlar mükemmel hizmet verseler bile, bireylerin kişilik özelliklerinden dolayı farklı bir algılama söz konusu olabilir.

Analiz sonucunda ortaya çıkan diğer önemli bulgu; destinasyon kalitesinin düşük veya yüksek olarak algılanmasında eğitim düzeyinin etkili olduğudur. Eğitim düzeyi yüksek (lisansüstü) olanların kalite algılarının daha pozitif olduğu görülmüştür. Benzer şekilde Jalilvand vd. (2014) eğitim düzeyi yüksek olanların destinasyona yönelik algılarının daha olumlu olduğunu tespit etmiş̧lerdir. Eğitim düzeyi yüksek olanların genellikle gelirleri de yüksek olmaktadır. Gelir düzeyi yüksek olan turistler daha konforlu yerlerde konaklayabilir, daha rahat ulaşım araçlarını kullanabilir, daha lezzetli yemekler yiyebilir. Nihayetinde birinci sınıf bir restoranın sunduğu 
hizmet ile sıradan bir restoranın hizmet aynı olmayacaktır. Bunun sonucunda orta veya düşük kaliteli olan yerleri görme ihtimali olmayacağından ve gittikleri yerler daha iyi ürün ve hizmet sunacağından destinasyona yönelik algılarının daha yüksek olması şaşırtıcı değildir. Yüksek eğitimin düzeyine sahip kişilerin destinasyon kalitesini daha pozitif algılamalarının bir diğer nedeni; eğitim düzeyi yüksek olan bireylerin tolerans düzeylerinin yüksek ve önyargılarının (Ardahan 2012, 47) az olmasıdır. Bu bağlamda destinasyonda sunulan bazı hizmetlerde aksaklık olduğunda, eğitim düzeyi yüksek insanlar daha sabırlı ve hoşgörü ile yaklaşabilmektedirler. Ancak eğitim düzeyi düşük insanların hizmete yönelik aksaklıklarda daha hızlı karar verme ve sert tepki gösterme eğilimleri olabilmektedir. Bundan dolayı kalite veya memnuniyet algısı eğitim düzeyinden etkilenebilmektedir.

Analizler sonucunda turistlerin geceleme sayısının, destinasyon kalitesinin algılanmasında negatif yönde bir etkisi olduğu ortaya çıkmıştır. Destinasyona geliş sayısının algılanan destinasyon kalitesi üzerinde etkili olduğu tespit edilmiştir (Jalilvand vd. 2014; Tosun vd. 2015). Bu çalışmada, sadece geliş sayısının yeterli olmayacağı düşünülerek geceleme sayısı da sorulmuştur. Turistlerden 10 ve üzerinde geceleme yapanların, destinasyon kalite algılarının daha negatif olduğu ortaya çıkmıştır. Bu bağlamda turistlerin destinasyon kalitesini daha pozitif algılaması için psikolojik eşiğin on gün olduğu söylenebilir. Turistler gittikleri destinasyonda turistik yerleri gezip gördükten sonra turistik olmayan veya alt yapı-üst yapı bakımından eksiklikleri olan yerleri görme şansı yakaladıklarında destinasyona yönelik memnuniyetleri veya kalite algıları düşebilir.

Bu çalışmada Güneydoğunun önemli kentlerinden Gaziantep ve Şanlıurfa'yı ziyaret eden turistlerin algıladıkları destinasyon kalitesinde eğitim düzeyinin, kişiliğin ve destinasyonda geceleme sayısının etkili olduğu tespit edilmiştir. Bu sözü edilen bölge için yapılan ender çalışmalardan birisidir. Bu çalışmada lojistik regresyon analizi ile turistlerin algıladıkları destinasyon kalitesinde etkili olabilecek unsurlar değerlendirilmiştir. Bundan sonra yapılacak çalışmalarda yöreyi ziyaret eden turistlerin motivasyon, beklenti, tatmin ve sadakatini ölçen araştırmaların yapılması ve talep yönünden eğilimlerinin belirlenmesi fayda sağlayabilir. 


\section{KAYNAKÇA}

Aksu A., İçigen E. T. \& Ehtiyar R. (2010). “A Comparison of Tourist Expectations and Satisfaction: A Case Study from Antalya Region of Turkey”. Turizam International Scientific Journal 14/2 (2010) 66-77.

Andreu L., Kozak M., Avci N. \& Cifter N. (2005). “Market Segmentation by Motivations to Travel: British Tourists Visiting Turkey”. Journal of Travel ve Tourism Marketing 19/1 (2005) 1-14.

Ardahan F. (2012). "Bireylerin Sosyal Sermaye Profili: Antalya Örneği”. Akademik Sosyal Araştırmalar Dergisi 2/8 (2012) 38-56.

Awaritefe O. D. (2003). “Destination Environment Quality and Tourists' Spatial Behaviour in Nigeria: A Case Study of Third World Tropical Africa”. International Journal of Tourism Research 5/4 (2003) 251-268.

Aykut O. H. (2013). Kişilik Özellikleri ile Tüketici Şikâyet Davranışı Arasındaki İlişkinin Incelenmesi. Yayımlanmamış Yüksek Lisans. Atatürk Üniversitesi, Erzurum 2013.

Baloglu S., Henthorne T. L. \& Sahin S. (2014). "Destination Image and Brand Personality of Jamaica: a Model of Tourist Behavior”. Journal of Travel ve Tourism Marketing 31/8 (2014) 1057-1070.

Barakazı M. \& Karapınar E. (2015). "Kültür Turizmi Potansiyelinin Seyahat Acenteleri Bakış Açısından Değerlendirilmesi: Gaziantep İlinde Bir Araştırma”. Uluslararası Sosyal Araştırmalar Dergisi 8/40 (2015) 609-619.

Bentler P. M. (1990). “Comparative fit indexes in structural models”. Psychological Bulletin 107/2 (1990) 238-246.

Biçer R. (2011). "Kişilik ve Bir Kur'an Terimi Olarak Şâkile”. Gazi University Journal of Gazi Educational Faculty 31/2 (2011) 399-418.

Borges N. J. \& Gibson D. D. (2005). "Personality Patterns of Physicians in Person-Oriented and Technique-Oriented Specialties”. Journal of Vocational Behavior 67/1 (2005) 4-20.

Bright A. D. (2008). "Motivations, Attitudes, and Beliefs". Eds. H. Oh and A. Pizam Handbook of Hospitality Marketing Management (2008) 239-265. UK.

Buhalis D. (2000). "Marketing the Competitive Destination of the Future". Tourism Management 21/1 (2000) 97-116.

Büyüköztürk Ş. (2016). Sosyal Bilimler İçin Veri Analizi El Kitabı. Ankara 2016.

Carr N. (2001). “An Exploratory Study of Gendered Differences in Young Tourists Perception of Danger Within London”. Tourism Management 22/5 (2001) 565-570.

Chen C. M., Lee H. T., Chen S. H. \& Huang T. H. (2011). “Tourist Behavioural Intentions in Relation to Service Quality and Customer Satisfaction in Kinmen National Park, Taiwan”. International Journal of Tourism Research 13/5 (2011) 416-432.

Chen, C. F. \& Tsai, D. (2007). "How Destination Image and Evaluative Factors Affect Behavioral Intentions?". Tourism Management 28(4): 1115-1122.

Cooper C., Fletcher, J., Gilbert D. \& Wanhill S. (1993). An Introduction to Tourism. Tourism: Principles and Practice. London 1993.

Costa P. T. \& McCrae R. R. (1985). “The NEO Personality Inventory”. Journal of Career Assessment 3/2 (1985) 123-139.

Costa P. T. \& McCrae R. R. (1995). "Domains and Facets: Hierarchical Personality Assessment Using the Revised NEO Personality Inventory”. Journal of Personality Assessment 64/1 (1995) 21-50.

Crompton J. L. (1979). “Motivations for Pleasure Vacation”. Annals of Tourism Research 6/4 (1979) 408-424.

Çetin B. (2015). Japon Turistlerin Seyahat Motivasyonlarının Turist Memnuniyeti ve Tekrar Ziyaret Etme Niyeti Üzerine Etkisi: Kapadokya Örneği. Yayımlanmamış Yüksek Lisans Tezi. Nevşehir Hac1 Bektaş Veli Üniversitesi, Nevşehir 2015.

Çokluk Ö., Şekercioğlu G. \& Büyüköztürk Ş. (2012). Sosyal Bilimler Iç̧in Çok Değişkenli İstatistik: SPSS ve LISREL Uygulamaları. Ankara 2012.

Dal V. (2009). Farklı Kişilik Özelliklerine Sahip Bireylerin Risk Algılarının Tüketici Davranışı Açısından Incelenmesi: Üniversite Öğrencileri Üzerine Bir Araştırma. Yayımlanmamış Yüksek Lisans Tezi. Süleyman Demirel Üniversitesi. Isparta 2009. 
Dann G. M. (1981). “Tourist Motivation an Appraisal”. Annals of Tourism Research 8/2 (1981) 187-219.

Della Corte V., Sciarelli M., Cascella C. \& Del Gaudio G. (2015). "Customer Satisfaction in Tourist Destination: The Case of Tourism Offer in the City of Naples". Journal of Investment and Management 4/1 (2015) 39-50.

Duman, T. \& Öztürk, A. B. (2005). "Yerli turistlerin Mersin Kızkalesi Destinasyonu ve Tekrar Ziyaret Niyetleri ile İlgili Algılamaları Üzerine Bir Araştırma". Anatolia: Turizm Araştırmaları Dergisi 16/1 (2005) 9-23.

Ekehammar B. \& Akrami N. (2007). "Personality and Prejudice: From Big Five Personality Factors to Facets”. Journal of Personality 75/5 (2007) 899-926.

Erkuş A. (2014). Psikolojide Ölçme ve Ölçek Geliştirme-I Temel Kavramlar ve Işslemler. Ankara 2014.

Eusébio C. \& Vieira A. L. (2011). "Destination Attributes' Evaluation, Satisfaction and Behavioural Intentions: A Structural Modelling Approach”. International Journal of Tourism Research 15/1 (2011) 66-80.

Faullant R., Matzler K. \& Mooradian T. A. (2011). "Personality, Basic Emotions, and Satisfaction: Primary Emotions in the Mountaineering Experience”. Tourism Management 32/6 (2011) 1423-1430.

Floyd F. J. \& Widaman K. F. (1995). "Factor Analysis in the Development and Refinement of Clinical Assessment Instruments”. Psychological Assessment 7/3 (1995) 286.

Fodness D. (1994). "Measuring Tourist Motivation”. Annals of Tourism Research 21/3 (1994) 555-581.

Ghada Abdalla M. (2008). "Egypt's Image as a Tourist Destination: A Perspective of Foreign Tourists”. Tourismos: An International Multidiscplinary Journal of Tourism 3/1 (2008) 36-65.

Gountas J. \& Gountas S. (2007). "Personality Orientations, Emotional States, Customer Satisfaction, and Intention to repurchase”. Journal of Business Research 60/1 (2007) 72-75.

Gountas J. \& Shaw R. (2001). "Personality, Quality and Satisfaction in Airline Services". Proceedings of the Australian and New Zealand Marketing Academy Conference (2001) 1-8.

Haghi H. \& Ooshaksaraie M. (2015). "Effect of Personality Factors and Satisfaction on Total Loyalty of Customers of Guilan Province Hotels Regarding Environment and Image of Hotels in Their View Point”. Humanities and Social Sciences 8/6 (2015) 164-170.

Harman S. (2012). Sirţ̧antalı Turistlerin Seyahat Motivasyonlart ve Ilgilenimleri: İstanbul'a Gelen Sirtçantal Turistler Üzerine Bir Araştırma. Yayımlanmamış Doktora Tezi. Çanakkale 18 Mart Üniversitesi, Çanakkale 2012.

Harman S. (2014). "Bağımsız Seyahat Eden Yerli Gezginlerin Profili ve Seyahat Alışkanlıkları Üzerine Bir Araştırma". Uluslararası Yönetim İktisat ve İşletme Dergisi 10/21 (2014) 273-297.

Heitmann S. (2011). “Tourist Behaviour and Tourism Motivation”. Ed. P. Robinson, S. Heitmann ve P. Dieke. Research Themes for Tourism (2011) 31-44. UK.

Hsu, C. H., Cai, L. A. \& Li, M. (2010)." Expectation, Motivation, and Attitude: A Tourist Behavioral Model". Journal of Travel Research 49/3 (2010) 282-296.

Iso-Ahola S. E. (1982). "Toward a Social Psychological Theory of Tourism Motivation: A Rejoinder". Annals of Tourism Research 9/2 (1982) 256-262.

Jackson M. \& Inbakaran R. (2006). Development of Personality Types to Predict Tourist Behaviour Towards Tourist Product Consumption. New Delhi 2006.

Jalilvand M. R., Samiei N., Dini B. \& Manzari P. Y. (2012). "Examining the Structural Relationships of Electronic Word of Mouth, Destination Image, Tourist Attitude Toward Destination and Travel Intention: an İntegrated Approach". Journal of Destination Marketing ve Management 1/1 (2012) 134-143.

Jang, S. \& Cai, L. A. (2002)." Travel Motivations and Destination Choice: A Study of British Outbound Market". Journal of Travel ve Tourism Marketing 13/3 (2002) 111-133.

Jani D. (2014). "Relating Travel Personality to Big Five Factors of Personality". Turizam: ZnanstvenoStručni Časopis 62/4 (2014) 347-359.

Jani D. \& Han H. (2014). Personality, Satisfaction, Image, Ambience and Loyalty: Testing Their Relationships in the Hotel Industry. International Journal of Hospitality Management 37 (2014) 11-20.

Jönsson C. \& Devonish D. (2008). "Does Nationality, Gender, and Age Affect Travel Motivation? A Case of Visitors to the Caribbean Island of Barbados”. Journal of Travel ve Tourism Marketing 25/3 
(2008) 398-408.

Kassarjian H. H. (1971). “Personality and Consumer Behavior: A Review”. Journal of Marketing Research 8/4 (1971) 409-418.

Kerse G. (2016). "Motivasyon Araçlarının Örgütsel Bağlılık Üzerindeki Etkisi: X ve Y Kuşağ1 Karşılaştırması”. Business and Management Studies: An International Journal 4/1 (2016) 1-23.

Kim S. \& Park E. (2015). "First-Time and Repeat Tourist Destination Image: The Case of Domestic Tourists to Weh Island, Indonesia”. Anatolia 26/3 (2015) 421-433.

Koçel T. (2012). Işsletme Yöneticiliği. İstanbul 2012.

Kondalkar V. G. (2007). Organizational Behaviour. New Delhi 2007.

Konu, H. \& Laukkanen, T. (2009). "Roles of Motivation Factors in Predicting Tourists' Intentions to Make Wellbeing Holidays-a Finnish Case". ANZMAC Conference Proceedings, http://www.duplication.net. au/ANZMAC09/papers/ANZMAC2009-376.pdf. (erişim tarihi: 16.12.2016).

Kozak M. (2001). "Comparative Assessment of Tourist Satisfaction with Destinations Across Two Nationalities”. Tourism Management 22/4 (2001) 391-401.

Kozak M. (2002). “Comparative Analysis of Tourist Motivations by Nationality and Destinations”. Tourism Management 23/3 (2002) 221-232.

Kozak M. \& Nield K. (1998). “Importance-Performance Analysis and Cultural Perspectives in Romanian Black Sea Resorts”. Anatolia 9/2 (1998) 99-116.

Lee T. H. (2009). “A Structural Model to Examine How Destination Image, Attitude, and Motivation Affect the Future Behavior of Tourists”. Leisure Sciences 31/3 (2009) 215-236.

Lin I. Y. \& Worthley R. (2012). "Servicescape Moderation on Personality Traits, Emotions, Satisfaction, and Behaviors". International Journal of Hospitality Management 31/1 (2012) 31-42.

López-Toro A. A., Diaz-Munoz R. \& Perez-Moreno S. (2010). “An Assessment of the Quality of a Tourist Destination: The Case of Nerja, Spain”. Total Quality Management 21/3 (2010) 269-289.

Mahika E. C. (2011). “Current Trends in Tourist Motivation”. Cactus Tourism Journal 2/2 (2011) 15-24.

Matzler K., Faullant R., Renzl B. \& Leiter V. (2005). “The Relationship Between Personality Traits (Extraversion and Neuroticism), Emotions and Customer Self-Satisfaction”. Innovative Marketing $1 / 2$ (2005) 32-39.

McAdams D. P. (1997). “A Conceptual History of Personality Psychology”. Handbook of Personality Psychology (1997) 3-39.

Merdan E. (2013). "Beş Faktör Kişilik Kuramı ile İş Değerleri İlişkisinin İncelenmesi: Bankacılık Sektöründe Bir Araştırma”. Gümüşhane Üniversitesi Sosyal Bilimler Enstitüsü Dergisi 4/7 (2013) 140-159.

Miller J. D. \& Lynam D. (2001). Structural Models of Personality and Their Relation to Antisocial Behavior: a Meta-Analytic Review. Criminology 39/4 (2001) 765-798.

Mills A. S. (1985). Participation Motivations for Outdoor Recreation: A Test of Maslow's Theory. Journal of Leisure Research 17/3 (1985) 184.

Mooradian T. A. \& Olver, J. M. (1997). ““I Can’t Get No Satisfaction:” The Impact of Personality and Emotion on Postpurchase Processes”. Psychology and Marketing 14/4 (1997) 379-393.

Morad Rezaei, D., Rezaei, H., Alipour, H. \& Salehi, S. (2011). Service Quality, Client Satisfaction and Client Personality in the Public Companies. Australian Journal of Basic and Applied Sciences 5/3 (2011) 483-491.

Morgan C. T. (2011). Psikolojiye Giriş. Çev. S. Karakaş ve R. Eski. Konya 2011.

Oliveira R. D., Cherubini M. \& Oliver N. (2013). "Influence of Personality on Satisfaction with Mobile Phone Services”. ACM Transactions on Computer-Human Interaction (TOCHI) 20/2 (2013) 10-23.

Özyurt P. M. \& Kantarci, K. (2014). “Determining Destination Quality from the Second Home Owners' Point of View”. European Journal of Tourism, Hospitality and Recreation Special Issue (2014) 127-141.

Pearce P. L. (1982). The Social Psychology of Tourist Behaviour. Oxford 1982.

Pearce P. L. \& Caltabiano, M. L. (1983). “Inferring Travel Motivation from Travelers' Experiences”. Journal of Travel Research 22/2 (1983) 16-20.

Plog S. (2001). "Why Destination Areas Rise and Fall in Popularity”. Cornell Hospitality Quarterly 42/3 
(2001).

Rızaoğlu B. (2012). Turizm Davranışı. Ankara 2012.

Ribeiro Soriano D. (2002). “Customers’ Expectations Factors in Restaurants: The Situation in Spain”. International Journal of Quality ve Reliability Management 19/8/9 (2002) 1055-1067.

Robbins S. P. \& Judge, T. A. (2012). Örgütsel Davranış. Çev. İ. Erdem. İstanbul 2012.

Shonk D. J. (2006). Perceptions of Service Quality, Satisfaction and the Intent to Return Among Tourists Attending a Sporting Event. Unpublished Doctoral Dissertation. The Ohio State University, Ohio 2006.

Siddiqui K. A. (2012). "Personality Influences on Customer Satisfaction”. African Journal of Business Management 6/11 (2012) 4134-4141.

Sönmez S. F. ve Graefe A. R. (1998). Determining Future Travel Behavior from Past Travel Experience and Perceptions of Risk and Safety. Journal of Travel Research 37 (1998) 171-177.

Şenel S. \& Alatlı B. (2014). "Lojistik Regresyon Analizinin Kullanıldığı Makaleler Üzerine Bir İnceleme”. Ĕgitimde ve Psikolojide Ölçme ve Değerlendirme Dergisi 5/1 (2014) 35-52.

Şentürk F. K. (2014). Etik Liderliğin Belirleyicileri Olarak Kişilik, Örgüt Kültürü, Dini Yönelim ve Çevresel Faktörler: Antalya'daki Dört ve Beş Yıldızlı Otellerde Bir Uygulama. Yayımlanmamış Doktora Tezi. Akdeniz Üniversitesi, Antalya 2014.

Tabachnick G. G. \& Fidell L. S. (2006). Using Multivariate Statistics. Boston 2006.

Tan H. H., Der Foo M. \& Kwek M. H. (2004). “The Effects of Customer Personality Traits on the Display of Positive Emotions”. Academy of Management Journal 47/2 (2004) 287-296.

Tasci A. D. (2009). "Social Distance the Missing Link in the Loop of Movies, Destination Image, and Tourist Behavior?”. Journal of Travel Research 47/4 (2009) 494-507.

Tosun C., Dedeoğlu B. B. \& Fyall A. (2015). "Destination Service Quality, Affective Image and Revisit Intention: The Moderating Role of Past Experience”. Journal of Destination Marketing ve Management 4/4 (2015) 222-234.

Um S. \& Crompton J. L. (1990). “Attitude Determinants in Tourism Destination Choice”. Annals of Tourism Research 17/3 (1990) 432-448.

Uysal M., Li X. \& Sirakaya-Turk E. (2008). "Push-Pull Dynamics in Travel Decisions”. Ed. H. Oh, Handbook of Hospitality Marketing Management (2008) 412-439. Heinemann.

Ünlüönen K. \& Çimen, H. (2011). “Destinasyon Kalitesi: İkinci Konut Sakinleri Örneği”. Elektronik Sosyal Bilimler Dergisi 10/35 (2011) 353-369.

Wang X., Zhang J., Gu C. \& Zhen F. (2009). "Examining Antecedents and Consequences of Tourist Satisfaction: A Structural Modeling Approach”. Tsinghua Science ve Technology 14/3 (2009) 397-406.

Wong, M., Cheung, R. \& Wan, C. (2013). "A Study on Traveler Expectation, Motivation and Attitude". Contemporary Management Research, 9/2 (2013) 169.

Woods M. \& Deegan J. (2003). “A Warm Welcome for Destination Quality Brands: The Example of the Pays Cathare Region”. International Journal of Tourism Research 5/4 (2003) 269-282.

Yazıcığlu İ. \& Akbulut B. A. (2016). "Yabancı Turistlerin Seyahat Motivasyonlarının Demografik Özellikleri Açısından Analizi: Ankara Örneği”. Journal of Human Sciences 13/2 (2016) 3231-3241.

Yuksel A., Yuksel F. \& Bilim, Y. (2010). “Destination Attachment: Effects on Customer Satisfaction and Cognitive, Affective and Conative Loyalty”. Tourism Management 31/2 (2010) 274-284.

Žabkar V., Brenčič M. M. \& Dmitrović T. (2010). "Modelling Perceived Quality, Visitor Satisfaction and Behavioural Intentions at the Destination Level”. Tourism Management 31/4 (2010) 537-546. 